\title{
Current scenario of peptide-based drugs: the key roles of cationic antitumor and antiviral peptides
}

\author{
Kelly C. L. Mulder, Loiane A. Lima, Vivian J. Miranda, Simoni C. Dias and Octávio L. Franco* \\ Programa de Pós-Graduação em Ciências Genômicas e Biotecnologia, Centro de Análises Proteômicas e Bioquímicas, Universidade Católica de Brasília, \\ Brasília, Brazil
}

\section{Edited by:}

Nádia S. Parachin, Universidade de Brasília-UnB, Brazil

\section{Reviewed by:}

Paul A. Hoskisson, University of Strathclyde, UK

Lilia Macovei, The Forsyth Institute, USA

\section{*Correspondence:}

Octávio L. Franco, Programa de Pós-Graduação em Ciências

Genômicas e Biotecnologia, Centro de Análises Proteômicas e

Bioquímicas, Universidade Católica de Brasília, SGAN 916N, Modulo C,

Avenue W5, Distrito Federal, Brasilia 71837-360, Brazil

e-mail:ocfranco@gmail.com
Cationic antimicrobial peptides (AMPs) and host defense peptides (HDPs) show vast potential as peptide-based drugs. Great effort has been made in order to exploit their mechanisms of action, aiming to identify their targets as well as to enhance their activity and bioavailability. In this review, we will focus on both naturally occurring and designed antiviral and antitumor cationic peptides, including those here called promiscuous, in which multiple targets are associated with a single peptide structure. Emphasis will be given to their biochemical features, selectivity against extra targets, and molecular mechanisms. Peptides which possess antitumor activity against different cancer cell lines will be discussed, as well as peptides which inhibit virus replication, focusing on their applications for human health, animal health and agriculture, and their potential as new therapeutic drugs. Moreover, the current scenario for production and the use of nanotechnology as delivery tool for both classes of cationic peptides, as well as the perspectives on improving them is considered.

Keywords: cationic peptides, antiviral, antitumor, target selectivity, therapeutic drugs

\section{INTRODUCTION}

Antimicrobial peptides (AMPs) are natural peptides found in microorganisms, plants, and animals, and are considered the evolutionarily conserved effectors in innate immunity (Hancock and Chapple, 1999; Hancock and Sahl, 2006). These peptides can be classified by physical-chemical properties such as cationic, anionic, hydrophilic, and amphipathic (Peter et al., 2010). Although they are diverse in length and sequence, two physicalchemical features are often the hallmarks of these molecules: they are cationic, often ranging from +2 to +7 at $\mathrm{pH} 7$, and amphipathic, therefore their stereogeometry confers relatively polarized hydrophilic and hydrophobic facets (Nguyen et al., 2011). Despite their structural conservation, they have a broad spectrum of activity such as antibacterial (Okubo et al., 2012; Tavares et al., 2012), antioxidative (Power et al., 2013), antihypertensive (Escudero et al., 2012), antifungal (Mandal et al., 2013), antiviral (Findlay et al., 2013), antitumor as well as modulation of the immune response (Silva et al., 2012). The modulation of the immune response role is specific to a group of peptides named host defense peptides (HDPs). Moreover, multiple functions may be associated with a single peptide according to the concept of promiscuity. They may act over different targets, therefore presenting different functions depending on their physical-chemical (namely pure promiscuity) or on their amino acid modification (namely family promiscuity) (Franco, 2011). These features confer to AMPs and HDPs many physiological advantages over other molecules for application in the field of drug development. As is summarized here, many AMPs and HDPs isolated from a wide variety of organisms including mammals, amphibians, insects, plants, and bacteria have been reported to have antiviral and/or antitumor activities. This review comprises their mechanisms of action and targets, as well as their potential as new therapeutic strategies to combat both viruses and malignant cells.

\section{CATIONIC ANTITUMOR PEPTIDES}

Cancer has become a major concern in relation to human morbidity and mortality. All types of cancer are characterized by irregular cell growth originating from a small number of inherited or environmentally-stimulated genetic mutations (Renan, 1993). Many strategies have been adopted to combat the propagation of cancer cells and their elevated growth such as chemotherapy, surgery, and radiation (Wang and Zhang, 2013). These typical procedures have often been revealed to be non-specific for cancer cells (Yang et al., 2013), additionally acting on the cell division of healthy cells, consequently impairing the restoration of normal tissues (Smith et al., 2000). Antitumor drugs are subject to differences in absorption, metabolism, and target tissue, which can be particular to each patient; moreover, tumors can be positioned in places into which drug penetration is impaired or possibly sheltered by restricted environments due to amplified hydrostatic pressure in the tissue or modified tumor vasculatures (Szakacs et al., 2006). Furthermore, the intrinsic or acquired drug resistance is considered the widespread cause for tumor recurrence (Szakacs et al., 2006).

Acknowledging the limitations of these currently available therapies, researchers have been encouraged to seek novel anticancer agents with only one exclusive mechanism of action (Szakacs et al., 2006; Hoskin and Ramamoorthy, 2008). In this context, natural AMPs from different sources and their synthetic analogs have been the basis for a number of studies performed to discover new therapies for treating malignant cells (Table 1). 
Table 1 | Cationic antitumor peptides from different sources, their application, and their mechanisms of action.

\begin{tabular}{|c|c|c|c|c|c|}
\hline Peptides & Source & Group & Application & Mechanism of action & References \\
\hline AGAP & Buthus martensii & Insect & $\begin{array}{l}\text { Lymphoma, leukemia, human } \\
\text { malignant glioma, human colon } \\
\text { cancer }\end{array}$ & Cell cycle arrest & $\begin{array}{l}\text { Cao et al., 2010; Zhao } \\
\text { et al., 2011; Gu et al., } \\
2013\end{array}$ \\
\hline Alloferon & Calliphora vicina & Insect & Leukemia & $\begin{array}{l}\text { Induces NK and } \\
\text { IFN-Immune-modulatory }\end{array}$ & Chernysh et al., 2002 \\
\hline Aplidine & Aplidium albicans & Tunicate & $\begin{array}{l}\text { Melanoma, non-small cell lung, } \\
\text { prostate, ovarian, colorectal }\end{array}$ & $\begin{array}{l}\text { Multifactorial apoptosis } \\
\text { inducer/cell cycle } \\
\text { arrest/inhibition of protein } \\
\text { synthesis }\end{array}$ & Faivre et al., 2005 \\
\hline Apratoxin A & $\begin{array}{l}\text { Lyngbya } \\
\text { majuscula }\end{array}$ & Cyanobacteria & HeLa (human cervical cancer) & Cell cycle arrest & Ma et al., 2006 \\
\hline Arenastatin A & Dysidia arenaria & Sponge & Human KB carcinoma & NR & Kobayashi et al., 1994 \\
\hline Aurein 1.2 & Litoria raniformis & Frog & $\begin{array}{l}\text { Leukaemia, lung, colon, CNS, } \\
\text { melanoma, ovarian, renal } \\
\text { prostate, breast }\end{array}$ & Barrel stave mechanism & Rozek et al., 2000 \\
\hline $\begin{array}{l}\text { BMAP-27 } \\
\text { BMAP-28 }\end{array}$ & Bos taurus & Mammal & $\begin{array}{l}\text { Leukemia, human } \\
\text { erythromyeloblastoid leukemia, } \\
\text { human leukemic monocyte } \\
\text { lymphoma }\end{array}$ & $\begin{array}{l}\text { Influx of } \mathrm{Ca}^{2+} \\
\text { DNA fragmentation } \\
\text { Increase membrane } \\
\text { permeabilization }\end{array}$ & Risso et al., 1998, 2002 \\
\hline Brevinin-2R & Rana ridibunda & Frog & $\begin{array}{l}\text { Leukemia, lymphoma, colon } \\
\text { carcinomas, fibrosarcoma, breast } \\
\text { adenocarcinoma, lung carcinoma }\end{array}$ & $\begin{array}{l}\text { Depolarize the } \\
\text { transmembrane } \\
\text { potential/lysossomal pathway }\end{array}$ & Ghavami et al., 2008 \\
\hline
\end{tabular}

\begin{tabular}{|c|c|c|c|c|c|}
\hline Buforin IIb & $\begin{array}{l}\text { Bufo bufo } \\
\text { gargarizans }\end{array}$ & Frog & $\begin{array}{l}\text { Leukemia, breast cancer, } \\
\text { non-small cell lung cancer, CNS } \\
\text { cancer, melanoma, renal, ovarian, } \\
\text { prostate and colon cancer }\end{array}$ & $\begin{array}{l}\text { Apoptosis by a } \\
\text { mitochondria-dependent } \\
\text { pathway/caspase-9 } \\
\text { activation/cytochrome c }\end{array}$ & Lee et al., 2008 \\
\hline
\end{tabular}

\begin{tabular}{|c|c|c|c|c|c|}
\hline Cecropins & $\begin{array}{l}\text { Hyalophora } \\
\text { cecropia }\end{array}$ & $\begin{array}{l}\text { Insect and } \\
\text { mammals }\end{array}$ & Leukemia, bladder & $\begin{array}{l}\text { Carpet } \\
\text { mechanism/Membrane } \\
\text { disruption }\end{array}$ & $\begin{array}{l}\text { Steiner et al., 1981; Chen } \\
\text { et al., 1997; Papo and } \\
\text { Shai, 2005; Lehmann } \\
\text { et al., 2006; Suttmann } \\
\text { et al., 2008; Xu et al., } \\
2008\end{array}$ \\
\hline $\begin{array}{l}\text { Cherimolacyclo } \\
\text { peptide C }\end{array}$ & Annona cherimola & Plant & Human KB carcinoma & NR & Wele et al., 2004 \\
\hline Citropin 1.1 & Litoria citropa & Frog & $\begin{array}{l}\text { Leukemia, lung, colon, CNS, } \\
\text { melanoma, ovarian, renal, } \\
\text { prostate, breast }\end{array}$ & Carpet mechanism & Doyle et al., 2003 \\
\hline Cn-AMP1 & Cocos nucifera & Plant & Colorectal adenocarcinoma & NR & Silva et al., 2012 \\
\hline Coibamide A & Leptolyngbya sp. & Cyanobacteria & $\begin{array}{l}\text { Breast, CNS, colon, melanoma, } \\
\text { leukemia, ovarian }\end{array}$ & Cell cycle arrest & Medina et al., 2008 \\
\hline CPAP & $\begin{array}{l}\text { Chlorella } \\
\text { pyrenoidosa }\end{array}$ & Algae & Human liver cancer & $\begin{array}{l}\text { Condensation/ fragmentation } \\
\text { of nuclear chromatin }\end{array}$ & Wang and Zhang, 2013 \\
\hline $\begin{array}{l}\text { Cr-ACP1 and } \\
\text { Cr-AcACP1 }\end{array}$ & Cycas revoluta & Plant & $\begin{array}{l}\text { Human epidermoid cancer, colon } \\
\text { carcinoma }\end{array}$ & Cell cycle arrest & Mandal et al., 2012 \\
\hline
\end{tabular}


Table 1 | Continued

\begin{tabular}{|c|c|c|c|c|c|}
\hline Peptides & Source & Group & Application & Mechanism of action & References \\
\hline CS5931 & Ciona savignyi & Tunicate & Human colorectal carcinoma & $\begin{array}{l}\text { Mitochondrial pathway of } \\
\text { apoptosis }\end{array}$ & Cheng et al., 2012 \\
\hline Cyclotide & Clitoria ternatea & Plant & Lung cancer & $N R$ & Sen et al., 2013 \\
\hline Cycloxazoline & $\begin{array}{l}\text { Lissoclinum } \\
\text { bistratum }\end{array}$ & Ascidian & $\begin{array}{l}\text { MRC5CVI fibroblasts, T24 } \\
\text { bladder carcinoma, leukemia }\end{array}$ & $\begin{array}{l}\text { Cell cycle arrest/inhibition of } \\
\text { cytokinesis }\end{array}$ & $\begin{array}{l}\text { Hambley et al., 1992; } \\
\text { Watters et al., } 1994\end{array}$ \\
\hline Dianthins $\mathrm{E}$ & $\begin{array}{l}\text { Dianthus } \\
\text { superbus }\end{array}$ & Plant & Liver hepatocellular cells & NR & Hsieh et al., 2004 \\
\hline Didemnin & $\begin{array}{l}\text { Trididemnun } \\
\text { solidum }\end{array}$ & Ascidian & Leukemia, melanoma & $\begin{array}{l}\text { Protein synthesis } \\
\text { inhibition/apoptosis }\end{array}$ & Rinehart et al., 1983 \\
\hline Dolastatin 10 & $\begin{array}{l}\text { Symploca sp., } \\
\text { Dolabella } \\
\text { auricularia }\end{array}$ & $\begin{array}{l}\text { Cyanobacteria, } \\
\text { mollusk }\end{array}$ & $\begin{array}{l}\text { Murine leukemia cells, lung } \\
\text { cancer }\end{array}$ & $\begin{array}{l}\text { Bcl-2 } \\
\text { phosphorylation/Caspase-3 } \\
\text { protein activation }\end{array}$ & $\begin{array}{l}\text { Bai et al., 1990; } \\
\text { Kalemkerian et al., } 1999\end{array}$ \\
\hline Gaegurins & Rana rugosa & Frog & $\begin{array}{l}\text { Kidney, lung, colon, breast, } \\
\text { stomach, liver, prostate, skin, } \\
\text { ovary }\end{array}$ & $\begin{array}{l}\text { Pore formation by } \\
\text { carpet-model }\end{array}$ & Won et al., 2006 \\
\hline Geodiamolide $\mathrm{H}$ & $\begin{array}{l}\text { Geodia } \\
\text { corticostylifera }\end{array}$ & Sponge & Breast cancer & $\begin{array}{l}\text { Altering the actin } \\
\text { cytoskeleton }\end{array}$ & Freitas et al., 2008 \\
\hline $\begin{array}{l}\text { Glidobactins A, } \\
\text { B and C }\end{array}$ & $\begin{array}{l}\text { Polyangium } \\
\text { brachysporum sp. }\end{array}$ & Bacterium & $\begin{array}{l}\text { Melanoma, leukemia, colon } \\
\text { carcinoma }\end{array}$ & $N R$ & Oka et al., 1988 \\
\hline Homophymines & Homophymia sp. & Sponge & $\begin{array}{l}\text { Pancreatic cancer, human } \\
\text { erythromyeloblastoid leukemia, } \\
\text { breast, liver hepatocellular, } \\
\text { human KB carcinoma, human } \\
\text { colon adenocarcinoma, human } \\
\text { ovarian, human prostate, } \\
\text { glioblastoma, lung epithelial cells }\end{array}$ & $N R$ & Zampella et al., 2009 \\
\hline $\begin{array}{l}\text { Human } \\
\text { alpha-defensin-1 }\end{array}$ & Homo sapiens & Human & Human lung adenocarcinoma & $\begin{array}{l}\text { Apoptosis by cytochrome c } \\
\text { from mitochondria } \\
\text { (mitochondrial pathway) }\end{array}$ & Xu et al., 2008 \\
\hline $\begin{array}{l}\text { Human } \\
\text { neutrophil } \\
\text { Peptides (HNP-1: } \\
\beta \text {-defensin) }\end{array}$ & Homo sapiens & Human & Leukemia and solid tumor & Induce membrane proteolysis & McKeown et al., 2006 \\
\hline Jamaicamide A & $\begin{array}{l}\text { Lyngbya } \\
\text { majuscula }\end{array}$ & Cyanobacterium & Human lung, neuroblastoma cell & NR & Edwards et al., 2004 \\
\hline Jaspamides & Jaspis splendens & Sponge & Lymphoma & $\begin{array}{l}\text { Caspase-3 } \\
\text { activation/decreasing in } \mathrm{Bcl}-2 \\
\text { protein expression }\end{array}$ & $\begin{array}{l}\text { Ebada et al., 2009; } \\
\text { Ghosh et al., } 2010\end{array}$ \\
\hline Kahalalide F (KF) & Elysia rufescens & Mollusk & $\begin{array}{l}\text { Colon, breast, non-small cell } \\
\text { lung, prostate carcinoma, } \\
\text { melanoma, hepatocellular } \\
\text { carcinoma }\end{array}$ & $\begin{array}{l}\text { Inhibit expression of genes } \\
\text { involved in DNA } \\
\text { replication/modifies lysosome } \\
\text { membrane/apoptosis inducer }\end{array}$ & $\begin{array}{l}\text { Hamann et al., 1996; } \\
\text { Gracia et al., 2006; Singh } \\
\text { et al., } 2008\end{array}$ \\
\hline Keenamide A & $\begin{array}{l}\text { Pleurobranchus } \\
\text { forskalii }\end{array}$ & Mollusk & $\begin{array}{l}\text { Leukemia, human lung } \\
\text { adenocarcinoma, human colon } \\
\text { adenocarcinoma }\end{array}$ & $N R$ & $\begin{array}{l}\text { Wesson and Hamann, } \\
1996\end{array}$ \\
\hline
\end{tabular}


Table 1 | Continued

\begin{tabular}{|c|c|c|c|c|c|}
\hline Peptides & Source & Group & Application & Mechanism of action & References \\
\hline Lactoferricin B & Bos taurus & Mammal & $\begin{array}{l}\text { Human leukemia, fibrosarcoma, } \\
\text { carcinoma, neuroblastoma }\end{array}$ & $\begin{array}{l}\text { Mitochondria pathway of } \\
\text { apoptosis/cytochrome c } \\
\text { release/activation of the } \\
\text { caspase cascade }\end{array}$ & $\begin{array}{l}\text { Mader et al., 2005; } \\
\text { Eliassen et al., } 2006\end{array}$ \\
\hline LL-37 & Homo sapiens & Human & Ovarian cancer & $\begin{array}{l}\text { Pore formation by } \\
\text { carpet-model }\end{array}$ & Chuang et al., 2009 \\
\hline Longicalycinin A & $\begin{array}{l}\text { Dianthus } \\
\text { superbus }\end{array}$ & Plant & Human liver carcinoma & NR & Hsieh et al., 2005 \\
\hline Lunasin & $\begin{array}{l}\text { Soybean and } \\
\text { other seeds }\end{array}$ & Plant & Breast cancer & NR & Hsieh et al., 2010 \\
\hline Lyngbyabellins & $\begin{array}{l}\text { Lyngbya } \\
\text { majuscula }\end{array}$ & Cyanobacterium & KB carcinoma & $N R$ & Williams et al., 2003 \\
\hline Magainins & Xenopus laevis & Frog & $\begin{array}{l}\text { Hematopoietic tumor, } \\
\text { melanoma, ovarian cancer, } \\
\text { bladder cancer, human cervical } \\
\text { carcinoma }\end{array}$ & $\begin{array}{l}\text { Mitochondria pathway of } \\
\text { apoptosis/Pore formation by } \\
\text { toroidal model/cytochrome c } \\
\text { release/activation of the } \\
\text { caspase cascade/Carpet } \\
\text { mechanism }\end{array}$ & $\begin{array}{l}\text { Zasloff, 1987; Cruciani } \\
\text { et al., 1991; Jacob and } \\
\text { Zasloff, 1994; Takeshima } \\
\text { et al., 2003; Lehmann } \\
\text { et al., } 2006\end{array}$ \\
\hline Malevamide D & $\begin{array}{l}\text { Symploca } \\
\text { hydnoides }\end{array}$ & Cyanobacterium & $\begin{array}{l}\text { Leukemia, lung cancer, human } \\
\text { colon carcinoma }\end{array}$ & $N R$ & Horgen et al., 2002 \\
\hline Melittin & Apis mellifera & Insect & Human hepatocellular carcinoma & $\begin{array}{l}\text { Influx of } \mathrm{Ca}^{2+} / \text { carpet } \\
\text { mechanism/toroidal pore }\end{array}$ & $\begin{array}{l}\text { Tosteson et al., 1985; } \\
\text { Wang et al., 2009a }\end{array}$ \\
\hline Mere15 & Meretrix meretrix & Bivalve & Human lung adenocarcinoma & $\begin{array}{l}\text { Induce release of cytochrome } \\
\text { c/cleavage of caspases/poly } \\
\text { ADP-ribose polymerase }\end{array}$ & Wang et al., 2012 \\
\hline Microcolin A & $\begin{array}{l}\text { Lyngbya } \\
\text { majuscule }\end{array}$ & Cyanobacterium & Breast carcinoma & Induction of apoptosis & Zhang and Longley, 1999 \\
\hline Mollamide & Didemnum molle & Ascidian & $\begin{array}{l}\text { Leukemia, human lung } \\
\text { carcinoma, human colon } \\
\text { carcinoma }\end{array}$ & NR & Carroll et al., 1994 \\
\hline Pardaxinis & $\begin{array}{l}\text { Pardachirus } \\
\text { marmoratus }\end{array}$ & Fish & Human sarcoma & $\begin{array}{l}\text { Elevation of caspase } \\
\text { activities, disruption of the } \\
\text { mitochondrial membrane }\end{array}$ & Huang et al., 2011 \\
\hline Phakellistatin 13 & Phakellia fusca & Sponge & Human hepatoma & $N R$ & Li et al., 2003 \\
\hline RA-XVII & $\begin{array}{l}\text { Rubiaceous } \\
\text { plants and Aster } \\
\text { tataricus }\end{array}$ & Plant & Leukemia & Activation of caspase activity & Hitotsuyanagi et al., 2004 \\
\hline Sansalvamide A & Fusarium ssp. & Fungi & $\begin{array}{l}\text { Pancreatic, colon, breast, and } \\
\text { prostate sarcoma, melanoma }\end{array}$ & Cell cycle arrest & Vasko et al., 2010 \\
\hline $\begin{array}{l}\text { Scopularide } A \\
\text { and } B\end{array}$ & $\begin{array}{l}\text { Scopulariopsis } \\
\text { brevicaulis and } \\
\text { Tethya Aurantium }\end{array}$ & $\begin{array}{l}\text { Marine fungi, } \\
\text { sponge }\end{array}$ & Pancreatic tumor, colon tumor & NR & Yu et al., 2008 \\
\hline $\begin{array}{l}\text { StAP1 and } \\
\text { StAP3 }\end{array}$ & $\begin{array}{l}\text { Solanum } \\
\text { tuberosum }\end{array}$ & Plant & Leukemia & Induces apoptosis & Mendieta et al., 2010 \\
\hline
\end{tabular}


Table 1 | Continued

\begin{tabular}{|c|c|c|c|c|c|}
\hline Peptides & Source & Group & Application & Mechanism of action & References \\
\hline Symplostatin 1 & Symploca sp. & Cyanobacterium & Breast, colon tumor & $\begin{array}{l}\text { Disrupts microtubules/mitotic } \\
\text { arrest/induces apoptosis }\end{array}$ & Mooberry et al., 2003 \\
\hline Tachyplesin I & $\begin{array}{l}\text { Tachypleus } \\
\text { tridentatus }\end{array}$ & $\begin{array}{l}\text { Japanese } \\
\text { horseshoe crab }\end{array}$ & $\begin{array}{l}\text { Human hepatocellular } \\
\text { carcinoma, prostate carcinoma }\end{array}$ & Non-cytolytic mechanism & Chen et al., 2005 \\
\hline $\begin{array}{l}\text { Tamandarins } A \\
\text { and } B\end{array}$ & $\begin{array}{l}\text { Family } \\
\text { Didemnidae }\end{array}$ & Ascidian & $\begin{array}{l}\text { Pancreatic carcinoma, prostatic } \\
\text { cancer, head and neck carcinoma }\end{array}$ & Protein synthesis inhibition & Vervoort et al., 2000 \\
\hline $\begin{array}{l}\text { Trapoxins A and } \\
\text { B }\end{array}$ & $\begin{array}{l}\text { Helicoma } \\
\text { Ambiens }\end{array}$ & Fungi & Colorectal cancer & NR & Itazaki et al., 1990 \\
\hline $\begin{array}{l}\text { Virenamides } \\
\text { A-C }\end{array}$ & Diplosoma virens & Ascidian & $\begin{array}{l}\text { Leukemia, human lung } \\
\text { carcinoma, human colon } \\
\text { carcinoma }\end{array}$ & Protein synthesis inhibition & Carroll et al., 1996 \\
\hline Viscotoxins & $\begin{array}{l}\text { Viscum } \\
\text { coloratum, } \\
\text { Viscum álbum }\end{array}$ & Plant & $\begin{array}{l}\text { Osteoblast-like Sarcoma, Yoshida } \\
\text { sarcoma (rat) }\end{array}$ & NR & Xu and Jin, 1999 \\
\hline Vitilevuamide & $\begin{array}{l}\text { Didemnum } \\
\text { cuculiferum } \\
\text { (Ascidians) }\end{array}$ & Ascidian & $\begin{array}{l}\text { Colon tumor, lung cancer, } \\
\text { melanoma, kidney cancer }\end{array}$ & $\begin{array}{l}\text { Tubulin polymerization/cell } \\
\text { cycle arrest }\end{array}$ & Edler et al., 2002 \\
\hline
\end{tabular}

NR, Not reported. KB, nasophryngeal cancer; CNS, central nervous system.

Cationic antitumor peptides have been suggested as promising agents for antitumor therapy due to their numerous advantages over other chemical agents such as their low molecular masses, relatively simple structures, greater specific cytotoxicity to tumor cells over healthy cells, fewer adverse reactions, ease of absorption, a variety of routes of administration and low risk for inducing multi-drug resistance (Alberts et al., 1980; Mader and Hoskin, 2006; Hoskin and Ramamoorthy, 2008; Schweizer, 2009; Riedl et al., 2011; Liu et al., 2013). They can also function in combination with conventional therapies and other potential anticancer molecules, usually improving the results of therapy (Chuang et al., 2009; Wang et al., 2009a). The intrinsic relationship between their chemical structure, i.e., their cationic and hydrophobic features, and their high specificity to tumor cells is likely to be the key role for their cytotoxicity. These characteristics allow the cationic AMPs to bind to and invade cancer cells, quickly disrupting membranes and leading to the outflow of intracellular contents and consequent cell death (Yeaman and Yount, 2003; Leuschner and Hansel, 2004; Jenssen et al., 2006). This happens due to the negatively-charged tumor cell membrane [derived from a greater than normal expression of anionic molecules such as sialic acid-rich glycoproteins, phosphatidylserine (PS) or heparan sulfate], which present essential differences with the neutrally-charged healthy cell membranes. Therefore, these chemical differences aid the electrostatic interaction of the positively-charged peptide and the negatively-charged tumor cell membranes (Dobrzynska et al., 2005; Hoskin and Ramamoorthy, 2008). The membranolytic mechanism was first discovered in a study of magainin and its synthetic analogs against hematopoietic and solid tumors (Cruciani et al., 1991). Cationic antitumor peptides might also induce disruption of intracellular targets by so-called non-membranolytic mechanisms. For instance, there are reports of antitumor peptides that cause necrosis by triggering intracellular apoptotic pathways (e.g., by inactivating mitochondria; activating caspase cascade) (Mader et al., 2005; Chen et al., 2012; Paredes-Gamero et al., 2012). Cationic antitumor peptides can also impair the activity of proteins of the signal transduction pathways involved in oncogene activities (Sharma, 1992). Both membranolytic and non-membranolytic mechanisms are discussed in this review and are represented in Figure 1.

Cationic peptides that kill cancer cells are arranged into two groups: (1) AMPs which are effective against bacteria and cancer cells but not against normal mammalian cells such as cecropins from insects and magainins from amphibians and (2) AMPs which are cytotoxic for bacteria, cancer cells, and normal mammalian cells such as melittin, tachyplesin II, human neutrophil defensins, and insect defensins (Papo and Shai, 2005; Hoskin and Ramamoorthy, 2008; Schweizer, 2009). It is believed that the difference between both groups relay mainly on the difference of the membrane of tumorous and normal cells (Hoskin and Ramamoorthy, 2008), therefore it would be essential to detailed understand these important changes at the molecular level. To date, it is here understood that besides the difference on the electrostatic charge between tumorous and normal cells cited above, the membrane fluidity may also interfere on the susceptibility of the peptide to disrupt the cells (Hoskin and Ramamoorthy, 2008). The fluidity of cancer cells is greater than that of mammalian normal cells (Sok et al., 1999) which may facilitate membrane destabilization favoring the binding of cationic antitumor peptides, and the amount of cholesterol, 


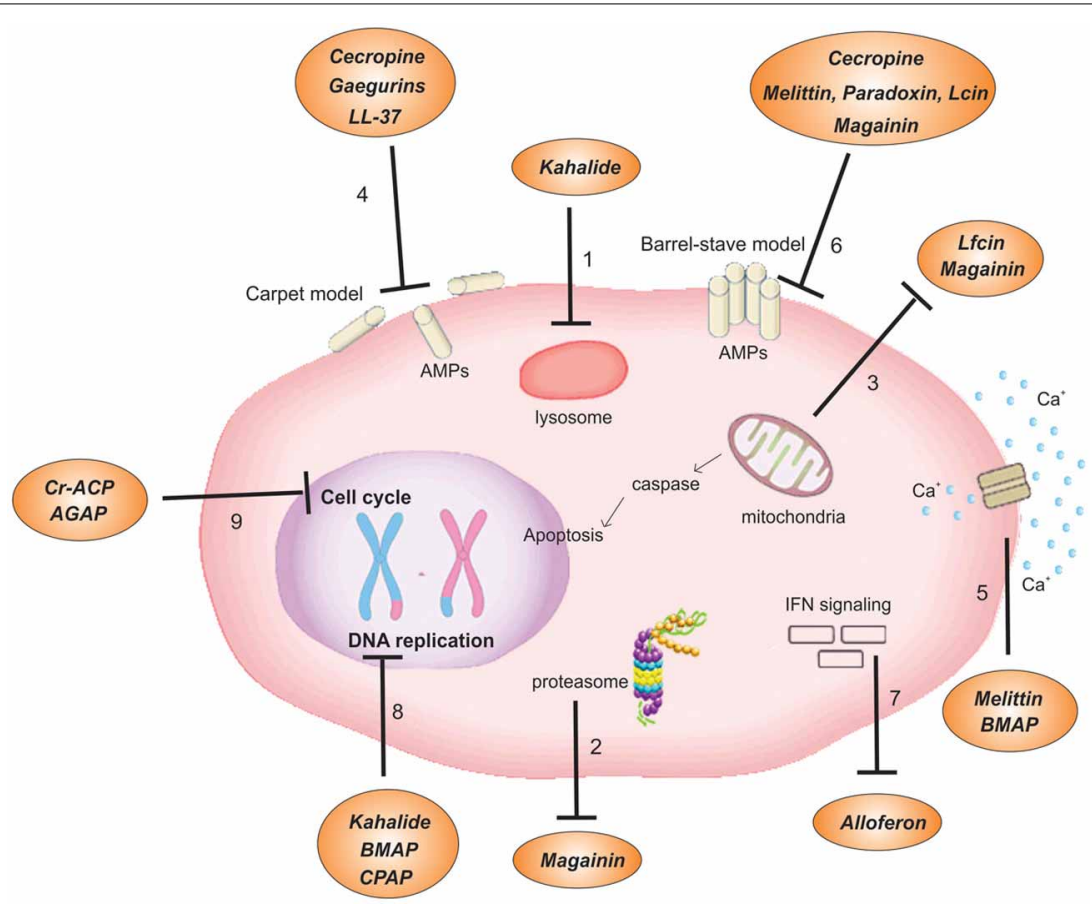

FIGURE 1 | Mechanisms of action of cationic antitumor peptides. (1) Modification of the lysosome membrane leading to an acidification of the intracellular environment and cell death. (2) Amplification of the proteasome activity. (3) Induction of mitochondrial pathway of apoptosis by either the cytochrome $c$ release into the cytoplasm or activation of the caspase cascade. (4) Pore formation by the carpet model. (5)
Increase of the influx of $\mathrm{Ca}^{2+}$. (6) Formation of pore by either the toroidal or the barrel-stave models. (7) Activation of an immune modulatory pathway by induction of NK and IFN. (8) Inhibition of genes involved in DNA replication. (9) Arrest of cell cycle G0, G1, or S phases. Lfcin, lactoferrcin; BMAP, bovine myeloid antimicrobial peptide; Cr-AMP, Chlorella pyrenoidosa antitumor polypeptide. the major component of eukaryotic cell membranes (Simons and Ikonen, 2000), alters the membrane fluidity, therefore protecting eukaryotic cells from cytolytic effects of antitumor peptides. For instance, membrane-insertion of the antitumor peptide cecropin is shown to reduced when synthetic lipid vesicles and Gram-negative bacteria have their cholesterol amount enhanced (Silvestro et al., 1999). Furthermore, the surface area of the membrane of tumorous cells, where the number of microvilli is higher than on non-tumorous cells (Chaudhary and Munshi, 1995), may also allow an increased number of peptides to bind to the membrane (Chan et al., 1998a,b).

In the following sections, cationic antitumor peptides from both groups which are derived from many sources including plants, vertebrates, and invertebrates will be presented (see Table 1).

\section{CATIONIC ANTITUMOR PEPTIDES ISOLATED FROM PLANTS}

High quantities of natural compounds and molecules from plants have been intensely studied for the treatment of a diverse number of diseases including cancer. Reviewed here is a specific class of cyclic peptides originally found only in plants as well as non-cyclic peptides with antitumor properties.

Clitoria ternatea is a rich source of a specific class of peptides named cyclotides, composed of a cyclic backbone combined with a conserved six cystine knot (Craik and Malik, 2013). A study carried out by Sen et al. (2013) has isolated five cyclotides named CT2, CT4, CT7, CT10, and CT12 (with an addition or removal of a net charge from -1 to +2 ) from this plant species. They showed significant cytotoxicity against human lung cancer cells (A549) and demonstrated a reduction of 2- to 4-fold of the $\mathrm{IC}_{50}$ (half maximal inhibitory concentration) value of cyclotides when compared to a mitotic inhibitor used in cancer chemotherapy. Moreover, these peptides were less cytotoxic against A549/paclitaxel (a sub-linage of A594) than only A549, which demonstrates a possible use of chemo-sensitization for treating cancer (Sen et al., 2013).

Along with cyclic peptides, many active non-cyclic antitumor peptides have also been isolated from different plants. For instance, the promiscuous peptide $C n$-AMP1, isolated and purified from coconut water (Cocos nucifera), was tested against CACO-2- human epithelial colorectal adenocarcinoma cells and showed a 13\% reduction of cell viability (Silva et al., 2012). Additionally, the peptide lunasin, isolated from soybeans and other seeds, was capable of suppressing in vitro and in vivo chemical carcinogen-induced tumorigenesis (Hsieh et al., 2010). StAP1 and StAP3, isolated from the potato Solanum tuberosum, were shown to induce apoptosis in Jurkat $\mathrm{T}$ leukemia cells (Mendieta et al., 2010; Guevara et al., 2011). Other examples are the peptides Cr-ACP, isolated from Cycas revoluta, and its acetylated-modified Cr-AcACP1, both repressors of cell proliferation of human epidermoid cancer (Hep2), and colon carcinoma through the induction of cell cycle arrest at the G0-G1 phase of Hep2 cells (Mandal et al., 2012). 
Among chlorophyllous organisms, few studies have been developed. One example is the polypeptide Chlorella pyrenoidosa antitumor polypeptide (CPAP) isolated from the unicellular green algae Chlorella pyrenoidosa. It has shown the highest inhibitory activity on human liver HepG2 cancer cells (49\%). CPAP induces apoptosis and necrotic death of HepG2 cells via membrane shrinkage, condensation and fragmentation of nuclear chromatin as well as formation of black apoptotic bodies (Wang and Zhang, 2013).

\section{CATIONIC ANTITUMOR PEPTIDES ISOLATED FROM INVERTEBRATES}

Bioactive peptides isolated from insects present many different activities and have strong potential as therapeutic agents (Table 1) (Chernysh et al., 2002). Cecropins, alloferons, and melittins are examples of AMPs isolated from insects which function as antitumor molecules with applications for various kinds of tumor cells (Figure 1). The AMP cecropin was first isolated from the giant silk moth Hyalophora cecropia (Steiner et al., 1981). Cecropins shares their potential antitumor activity with structural analogs from other families of AMPs such as magainins and defensins (Papo and Shai, 2005; Lehmann et al., 2006). It has been shown that two cecropin B analogs, cecropin B1 (CB1) which possesses two amphipathic helices, and cecropin B3 (CB3) which has two hydrophobic helices, exhibit strong cytotoxic activity against a number of human leukemia cell lines and do not lyse normal fibroblasts or erythrocytes (Srisailam et al., 2001). Both analogs exhibit drastically different mechanisms of actions on anionic lipid vesicles and show the importance of the structure and sequence of a cationic antitumor peptide and its potency toward different cancer cells (Srisailam et al., 2001). It has been claimed that the discontinuous helical segments in the structure of CB3 do not favor helix-helix interactions which are crucial for pore formation; these mechanisms are likely to be adopted by CB1 where the continuous helical conformation interacts with cellsurface structures such as microvilli in cancer cells. In a different study, CB1 was a more powerful cytolytic agent than cecropin B against HL-60 human promyelocytic leukemia cells (Chan et al., 1998a,b). Cecropin A and B have been shown to reduce the viability of bladder cancer cells (Suttmann et al., 2008) and to directly induce tumor cell lysis via cell membrane disruption, which stimulates cytolysis/necrosis. Furthermore, it was shown that these peptides are capable of imposing the disruption of mitochondrial membranes, consequently leading to the activation of apoptosis pathways (Suttmann et al., 2008).

Another important AMP isolated from insects is alloferon: a tridecapeptide isolated from the bacteria-challenged larvae of the blow fly Calliphora vicina. Synthetic alloferon I has been shown to act on tumor growth control in two different ways. It stimulates natural killer (NK) lymphocytes and interferon (IFN) in vitro by using mouse spleen lymphocytes and human blood mononuclear cells. The peptide was administrated in picomolar concentrations where its potential to stimulate natural cytotoxicity in these models was confirmed. Alloferon also induces IFN synthesis in vivo which was demonstrated using animal and human models, and consequently enhancing its antitumor activity (Figure 1). Based on these results, the researchers have suggested an interaction of alloferon anticancer activity with its immunomodulatory properties. The interferonogenic activity was more evident in vitro using human cells than in vivo, while in comparison to mouse cells the opposite result was observed. The NK-IFN network is well-documented and demonstrates the potential immune modulatory properties of this AMP. Furthermore, it has been recently shown that the combination of chemotherapy and alloferon I, referred to as pulse immune chemotherapy, demonstrated significant advantages compared to each treatment applied separately (Chernysh et al., 2002, 2012).

Also from the group of insects, the AMP melittin, isolated from Apis mellifera, is also an active molecule against antitumor cells. It is cytotoxic against human hepatocellular carcinoma (Tosteson et al., 1985; Wang et al., 2009a). Studies indicate that melittin damages cell membranes either via the barrel-stave mechanism, i.e., it acts under its membranolytic properties (Sui et al., 1994), or via its non-membranolytic properties through a mechanism that engages the hyperactivation of phospholipase A2 and the influx of $\mathrm{Ca}^{2+}$, resulting in the destruction of the transformed cells (Figure 1) (Sharma, 1992, 1993).

Another antiviral AMP within the group of invertebrates is the peptide AGAP isolated from the scorpion Buthus martensii. It has been reported to possess both analgesic and antitumor activities. Recently, a heterologous expression system has been constructed using small ubiquitin-related modifier-AGAP (SUMO-AGAP) which is a product of recombinant AGAP (rAGAP) linked with a hexa-histidine tag from Escherichia coli. This recombinant system showed considerable inhibition of lymphoma and glioma propagation (Gu et al., 2013). Using SW480 human colon cancer cells, it was proposed that rAGAP induces cell cycle arrest in the G0/G1 phase, attended by the decrease in the $S$ phase without significant change in the G2/M phase (Gu et al., 2013).

Other sources of cationic peptides isolated from invertebrates are found in the marine ecosystem. The biodiversity of this environment has been shown to be a rich source of biologically active molecules and has been considered an unlimited resource of new antitumor agents (Zheng et al., 2011; Malaker and Ahmad, 2013). Several AMPs with antitumor activity have been isolated from marine invertebrates such as cyclic depsipeptide didemnins. Isolated from the ascidian of the genus Trididemnum, it has shown antitumor activity against L1210 leukemia cells in vitro and P388 leukemia and B16 in vivo (Rinehart et al., 1983). The antitumor role of the peptide kahalaide $\mathrm{F}$ from Elysia rufescens, a marine gastropod mollusk, has also been reported. It has shown significant in vitro and in vivo activity against non-small cell lung cancer, colon and human breast tumor cell lines, melanoma, androgen-independent prostate cancer and hepatocellular carcinoma (Martin-Algarra et al., 2009; Malaker and Ahmad, 2013). This peptide acts on the liposome membrane of tumor cells and modifies its basal function (Figure 1) (Hamann et al., 1996; Singh et al., 2008). Moreover, it modifies the role of the lysosomal membrane, leading to intracellular acidification and cell death, a characteristic that discriminates it from all other known antitumor agents (Gracia et al., 2006). This peptide also appears to inhibit the expression of certain specific genes that are involved in DNA replication and cell proliferation, thereby inhibiting tumor spreading and growth. Recently another marine AMP isolated from the bivalve Meretrix meretrix, named mere15, has shown to 
significantly inhibit the growth of human lung adenocarcinoma A549 xenograft in nude mice (Wang et al., 2012).

\section{CATIONIC ANTITUMOR PEPTIDES ISOLATED FROM VERTEBRATES}

Many peptides have been discovered from a variety of vertebrates that are responsible for improving the innate immune response (Table 1) They have been found at relatively low concentrations in the normal tissues of mammals and are usually present within the granules of neutrophils, in mucosal or skin secretions from epithelial cells, and as the degradation products of proteins (Boman, 1995; Hancock, 2001). Among the mammalian organisms, bovines have been a promising source of molecules which show a broad range of physiological activities, including immune function enhancement and defense against pathogenic bacteria and viruses. Among these molecules, three AMPs named BMAP-27, BMAP-28 and lactoferricin have been reported as active antitumor peptides. The bovine myeloid AMPs BMAP-27 and BMAP-28 (27 and 28 amino acid residues, respectively) have shown cytotoxic activity against neoplastic cells. These peptides, when tested against fresh tumor leukocytes from patients affected by myeloid or lymphoid leukemia, have shown to increase membrane permeabilization and the influx of $\mathrm{Ca}^{2+}$, followed by DNA fragmentation, which is characteristic of programmed cell death (Figure 1) (Risso et al., 1998).

The cytotoxic activity of bovine lactoferricin (LfcinB) has been demonstrated in vitro with different rat and human cancer cell lines including leukemia, fibrosarcoma, various carcinoma, and neuroblastoma cells, and did not influence the viability of normal fibroblasts, lymphocytes, epithelial cells, endothelial cells, or erythrocytes (Yoo et al., 1997; Mader et al., 2005; Eliassen et al., 2006). It has been proposed that Lfcin targets tumor cells by the changes that occur in their cell membranes, such as the exposure of negatively-charged head-groups derived from the loss of phospholipid asymmetry in diseased cells (Gifford et al., 2005; Pepe et al., 2013). The activities against fibrosarcoma and neuroblastoma rat cells and human T-leukemia cells can be described by a mechanism that induces the formation of transmembrane pores allowing the peptide to enter the cytoplasmic compartment of the cancer cell, co-localize with negatively-charged mitochondria and consequently depolarize them, resulting in cytochrome $\mathrm{C}$ release or activation of the caspase cascade, thereby leading to cell death via apoptosis (Figure 1) (Mader et al., 2005; Pepe et al., 2013). Moreover, it may interfere with the interaction between growth factors and their receptors on the surface of endothelial cells, resulting in decreased endothelial cell proliferation and diminished angiogenesis (Mader et al., 2006). As reviewed by Gifford and colleagues, other mechanisms have been proposed. In brief, upon binding to the tumor cells, Lfcin is thought to trigger a $\mathrm{Ca}^{2+} / \mathrm{Mg}^{2+}$ endonuclease and oxidant-dependent apoptotic pathway. Although the structural parameters that describe the antitumor effects of Lfcin are very similar to those that describe its antibacterial activity, a higher net positive charge ( +7 when compared to +4 for antibacterial activity) is required for antitumor activity to promote a strong electrostatic interaction between the peptide and the membrane (Figure 1) (Gifford et al., 2005).

Among the human-derived mammalian AMPs, the amphipathic $\alpha$-helical LL-37 has been extensively studied as an antibacterial peptide. Besides its strong activity against bacteria, it has also shown to be cytotoxic against ovarian cancer (Chuang et al., 2009) and is toxic to eukaryotic cells at a slightly higher concentration (25-30 mM) (Hoskin and Ramamoorthy, 2008). Regarding its mechanism of action, it is known that upon binding to membranes it changes the head group conformation of phospholipids, induces positive curvature strain on lipid bilayers, and significantly disorders the hydrophobic core of the membranes, exhibiting the carpet-like rather than the channel/pore-forming mechanism of cytotoxicity (Figure 1) (Henzler Wildman et al., 2003; Henzler-Wildman et al., 2004; Hoskin and Ramamoorthy, 2008).

Within the class of amphibians, the order Anura has been shown to be a rich source of AMPs. Their skin has diverse physiological activities and forms an essential part of their defense systems. In response to a multiplicity of stimuli, AMPs can be secreted from specific glands onto the dorsal surface and into the gut of the amphibian (Bevins and Zasloff, 1990; Barra and Simmaco, 1995; Doyle et al., 2003).

In comparison to synthetic magainins $\mathrm{A}, \mathrm{B}$, and $\mathrm{G}$, the natural peptide magainin-2, isolated from the skin of the frog Xenopus laevis, is the most efficient peptide and causes fast lysis of hematopoietic and solid tumor cell lines including many human bladder cell lines (Cruciani et al., 1991; Jacob and Zasloff, 1994). Magainin-2 has been shown to enter the cell membrane of HeLa human cervical carcinoma cells by binding numerous magainin helices forming a toroidal pore in the lipid molecules of artificial membranes (Matsuzaki et al., 1996). It has also been reported that pore formation is followed by a dispersing membrane potential and leakage of intracellular molecules, consequently leading to cell death (Takeshima et al., 2003). Magainin are shown to access the cytosolic compartment of cancer cells and cause the mitochondrial pathway of apoptosis via a mechanism that involves cytochrome c release into cytoplasm and an amplified proteasome activity, confirming its apoptotic effect (all these mechanisms are shown in Figure 1) (Westerhoff et al., 1989; Cruz-Chamorro et al., 2006).

Another example of potential antitumor AMPs belonging to the order Anura are gaegurin and buforin. The peptide gaegurin was purified from the skin of the Korean frog Rana rugosa. It is a potent mediator of cytolysis using either the carpet or barrelstave mechanism (Park et al., 1994; Hoskin and Ramamoorthy, 2008) and is also reported to follow the mitochondria pathway of apoptosis as described above for the magainin mechanism of action (Li et al., 2000; Mai et al., 2001).

Buforin II, a linear $\alpha$-helical peptide similar to cecropins and magainins, was isolated from the stomach of the Bufo bufo gargarizans and is known to penetrate cell membranes through nonpermeabilizing pore-like structures which allow its translocation into the cytoplasm without cell lysis, and consequently inhibits intracellular functions (Park et al., 1998). It has been shown that the cytotoxic activity of buforin II is low when compared with citropin 1.1, pexiganan MSI-78 and protegrin 1, and that it does not permanently disrupt the cell membrane like other molecules, i.e., its antitumor activity corroborates with the mechanism described above (Koszalka et al., 2011). A synthetic analog of buforin II named buforin IIb has shown greater cytolytic activity against 
cancer cells (leukemia, breast cancer, non-small cell lung cancer, CNS cancer, melanoma, renal, ovarian, prostate, and colon cancer) than buforin II (Lee et al., 2008).

From the group of marine vertebrates, the cationic peptide pardaxin isolated from the small fish Pardachirus marmoratus has been shown to be a potential active antitumor peptide against human sarcoma (Huang et al., 2011). It has been reported that this peptide disrupts the membrane via the barrel-stave mechanism (Hallock et al., 2002), and changes its transmembrane orientation depending on membrane composition (Hoskin and Ramamoorthy, 2008).

\section{CATIONIC ANTIVIRUS PEPTIDES}

The success of viruses in evolution has been assured by four general attributes: genetic variation, variety in means of transmission, efficient replication within host cells, and the ability to persist in the host (Wagner et al., 1999). Due to these attributes, the control of viral diseases has not been an easy task. Despite the existence of antiviral drugs, there is a need to explore novel antiviral compounds in order to control emerging viral pathogens. In this perspective, AMPs are an alternative in drug design. Several cationic antiviral peptides from various sources have been isolated since the 1980s (Table 2) and they have shown strong potential for novel therapeutic drugs against many viral infections. Due to the promiscuity of these peptides, it is possible to verify a broad spectrum of antiviral activities within the same peptide. Moreover, this promiscuous activity can be extended to simultaneous cytotoxic activity against tumor cells (Figure 2). The first study reporting an antiviral role of a cationic peptide was published in 1986, in which the activity of $\alpha$-defensin was described as inhibiting a number of viruses including herpes simplex virus types 1 and 2 (HSV), cytomegalovirus (CMV) as well as inhibiting the vesicular stomatitis virus with human neutrophil peptide 1 (HNP1) in vitro (Daher et al., 1986; Findlay et al., 2013). Since then, many reports have shown the antiviral activity of cationic host-defense peptides such as $\alpha-, \beta$-, and $\theta$-defensins, and the use of effective antiviral therapy with cathelicidins, as previously reviewed (Findlay et al., 2013). It is very promising that in the last years many new antiviral peptides have been either identified or synthesized in order to aid the development of new therapeutic antivirus therapies.

\section{CATIONIC ANTIVIRAL PEPTIDES DRUGS APPLIED TO HUMAN HEALTH}

Cationic antiviral peptides have been isolated from various sources and present broad antiviral activities against several viruses with different antiviral mechanisms of action (Table 2). They can either inhibit viral attachment by binding to viral targets on the host cell surface, or target viral proteins, therefore blocking viral fusion and entry into the host cell. Another mechanism of action is intracellularly driven where spreading of the virus is inhibited through the suppression of viral gene expression, inhibition of translation or by immune modulatory activities (Figure 3).

\section{CATIONIC ANTIVIRAL PEPTIDES ISOLATED FROM INVERTEBRATES}

AMPs isolated from the group of invertebrates which present strong antiviral activity against maladies that affect human health are well-represented by peptides such as melittin, cecropin, and alloferon. Described above as an antitumor peptide, melittin has also been reported to have inhibitory activity against enveloped viruses such as HIV-1, HSV-2, and the Junin virus (JV), an arenavirus, including this peptide under the concept of promiscuity (Figure 2). A proposed mechanism of action has suggested that melittin suppresses cell fusion mediated by HSV-1 syncytial mutants probably by interfering with the activity of the $\mathrm{Na}^{+} \mathrm{K}^{+}$ ATPase, a cellular enzyme involved in the membrane fusion process (Albiol Matanic and Castilla, 2004). Analysis of the effect of melittin on the production of HIV-1 transcripts was assayed in acutely infected T-cells cultured with various concentrations of melittin. Levels of all HIV-1 transcript classes were suppressed (reduction of $\sim 30 \%$ when compared with cells without melittin) in a dose-dependent manner (Wachinger et al., 1998). Another mechanism whereby melittin interferes with viral gene expression has been proposed and involves intracellular immunization against HIV (Figure 3). Melittin interfere in the process of cellular signal transduction, such as the activation of phospholipase A2 for instance, and the decrease in activities of calmodulin and protein kinase C (Sharma, 1993; Fisher et al., 1994; Gravitt et al., 1994). These properties may therefore change the balance and activities of cellular stimulators of HIV transcription (as NFkB, AP-1 and NFAT) or induce inhibitory factors (interferon-induced cellular inhibitor) (Wachinger et al., 1998).

The peptides alloferon 1 and 2 have shown activity against the influenza virus, through the same mechanism described above for its role as an antitumor peptide, by induction of immune modulatory activities. Both activities against tumor and viral infections emphasize the mechanisms of cell-mediated natural cytotoxicity and IFN synthesis (Figure 3). Therefore, these peptides seem to be potential candidates as biopharmaceutical compounds containing the capability of improving important effector mechanisms of the innate immune response (Chernysh et al., 2002).

Another example of invertebrate peptides with antivirus activity against human virus-related diseases is the synthetic peptide T22 ([Tyr5, 12, Lys7]-polyphemusin II), which is associated with the promiscuous peptide tachyplesin (Figure 2) and the peptide polyphemusin, which are abundant in the hemocytes of the horseshoe crab Tachypleus tridentatus and Limulus polyphemus, respectively. It has shown potent antiviral activity against HIV1 and HIV-2 in vitro. The inhibitory activity of this peptide is related to its specific binding to a chemokine receptor CXCR4, which serves as a co-receptor for the entry of HIV-1 into T cells (Figure 3) (Nakashima et al., 1992; Tamamura et al., 1998).

\section{CATIONIC ANTIVIRAL PEPTIDES ISOLATED FROM VERTEBRATES}

There are several AMPs derived from mammalian sources which have demonstrated strong activity against many viruses that compromise human health (Table 2 ). In this group are included defensins, Lfcin and LL-37 (Figure 2). Defensins are potent candidates for the development of antiviral drugs. They are peptides with conserved structures, usually with $\alpha$-helix and antiparallel $\beta$-sheets stabilized by disulfide bonds (Terras et al., 1992; Bastian and Schafer, 2001; Franco et al., 2006), and belong to three subfamilies, designated $\alpha, \beta$, and $\theta$ defensins. The HNP- 1 is an $\alpha$ defensin that have been widely tested for its antiviral activity. This 
Table 2 | Cationic antiviral peptides from different sources, their application, and their mechanisms of action.

\begin{tabular}{|c|c|c|c|c|c|}
\hline Peptide & Source (s) & Group & Application & Mechanism of action & References \\
\hline \multicolumn{6}{|l|}{ HUMAN HEALTH } \\
\hline $\begin{array}{l}\text { Alloferon } 1 \\
\text { Alloferon } 2\end{array}$ & Calliphora vicina & Insect & IAV & $\begin{array}{l}\text { Immunomodulatory } \\
\text { activity }\end{array}$ & Chernysh et al., 2002 \\
\hline Brevinin-1 & Rana brevipoda & Frog & HSV & Viral inactivation & Yasin et al., 2000 \\
\hline CAP37 & Homo sapiens & $\begin{array}{l}\text { Human } \\
\text { leococytes }\end{array}$ & $\begin{array}{l}\text { HSV-1 } \\
\text { AdV }\end{array}$ & $\begin{array}{l}\text { Disrupts the envelope } \\
\text { and/or capsid }\end{array}$ & Gordon et al., 2009 \\
\hline Cecropin & Hyalophora cecropia & Insect & $\begin{array}{l}\text { JV } \\
\text { HSV } \\
\text { HIV }\end{array}$ & $\begin{array}{l}\text { Suppresses viral protein } \\
\text { synthesis Cellular target } \\
\text { Suppresses viral gene } \\
\text { expression }\end{array}$ & $\begin{array}{l}\text { Wachinger et al., 1998; Albiol } \\
\text { Matanic and Castilla, } 2004\end{array}$ \\
\hline Defensin & Homo sapiens & Human & $\begin{array}{l}\text { HSV } \\
\text { IAV } \\
\text { HCMV } \\
\text { VSV } \\
\text { HIV } \\
\text { AdV }\end{array}$ & $\begin{array}{l}\text { Interacts with } \\
\text { glycosaminoglycans } \\
\text { Inactivates viral particle } \\
\text { Cellular target } \\
\text { Unknown }\end{array}$ & $\begin{array}{l}\text { Daher et al., 1986; Nakashima } \\
\text { et al., 1993; Gropp et al., 1999; } \\
\text { Yasin et al., 2000; Bastian and } \\
\text { Schafer, 2001; Sinha et al., } 2003\end{array}$ \\
\hline Dermaseptin & Genus Phyllomedusa & Frog & $\begin{array}{l}\text { HIV } \\
\text { HSV }\end{array}$ & Disruptis viral membrane & Belaid et al., 2002 \\
\hline $\begin{array}{l}\text { Didemnins A } \\
\text { Didemnins B }\end{array}$ & Genus Trididemnum & Tunicate & $\begin{array}{l}\text { HSV } \\
\text { Parainfluenza } \\
\text { Dengue } \\
\text { virus }\end{array}$ & $\begin{array}{l}\text { Inhibits RNA and DNA viral } \\
\text { replication }\end{array}$ & $\begin{array}{l}\text { Rinehart et al., 1981; Aneiros and } \\
\text { Garateix, } 2004\end{array}$ \\
\hline Indolicidin & Bos taurus & Bovine & $\begin{array}{l}\text { HIV } \\
\text { HSV }\end{array}$ & $\begin{array}{l}\text { Inhibits integrase } \\
\text { Targets viral } \\
\text { glycosaminoglycans }\end{array}$ & Robinson et al., 1998 \\
\hline Lactoferricin & $\begin{array}{l}\text { Homo } \\
\text { sapiens } \\
\text { Bos taurus }\end{array}$ & Human, Bovine & $\begin{array}{l}\text { HCMV } \\
\text { HIV } \\
\text { HSV } \\
\text { Papilloma }\end{array}$ & $\begin{array}{l}\text { Activity at virus-cell } \\
\text { interface } \\
\text { Blocks heparan sulfate }\end{array}$ & $\begin{array}{l}\text { Andersen et al., 2001; Jenssen } \\
\text { et al., 2004; Mistry et al., } 2007\end{array}$ \\
\hline LL-37 & Homo sapiens & Human & $\begin{array}{l}\text { HSV } \\
\text { IAV }\end{array}$ & $\begin{array}{l}\text { Viral receptor-based } \\
\text { mechanisms }\end{array}$ & $\begin{array}{l}\text { Yasin et al., 2000; Barlow et al., } \\
2011\end{array}$ \\
\hline Magainin & Xenopus laevis & Frog & $\begin{array}{l}\text { HSV } \\
\text { HIV }\end{array}$ & $\begin{array}{l}\text { Suppresses viral gene } \\
\text { expression }\end{array}$ & $\begin{array}{l}\text { Aboudy et al., 1994; Albiol } \\
\text { Matanic and Castilla, } 2004\end{array}$ \\
\hline Mellitin & Apis mellifera & Insect & $\begin{array}{l}\mathrm{HSV} \\
\mathrm{JV}\end{array}$ & Cellular target & $\begin{array}{l}\text { Wachinger et al., 1998; Yasin } \\
\text { et al., 2000; Albiol Matanic and } \\
\text { Castilla, } 2004\end{array}$ \\
\hline Microspinosamide & $\begin{array}{l}\text { Sidonops } \\
\text { microspinosa }\end{array}$ & Marine sponge & HIV & $\begin{array}{l}\text { Inhibits cytopathic effect of } \\
\text { HIV-1 infection }\end{array}$ & Rashid et al., 2001 \\
\hline
\end{tabular}


Table 2 | Continued

\begin{tabular}{|c|c|c|c|c|c|}
\hline Peptide & Source (s) & Group & Application & Mechanism of action & References \\
\hline PAP & Phytolacca americana & Plant & $\begin{array}{l}\text { HIV } \\
\text { HBV } \\
\text { HSV }\end{array}$ & $\begin{array}{l}\text { Inhibits viral protein } \\
\text { synthesis }\end{array}$ & Kaur et al., 2011 \\
\hline Protegrin & Homo sapiens & Human & $\begin{array}{l}\text { HIV } \\
\text { HSV }\end{array}$ & $\begin{array}{l}\text { Unknown } \\
\text { Viral inactivation }\end{array}$ & $\begin{array}{l}\text { Yasin et al., 2000; Steinstraesser } \\
\text { et al., } 2005\end{array}$ \\
\hline Tachyplesin & $\begin{array}{l}\text { Tachypleus } \\
\text { tridentatus }\end{array}$ & Horseshoe crab & $\begin{array}{l}\text { HIV } \\
\text { HSV } \\
\text { VSV } \\
\text { IAV }\end{array}$ & $\begin{array}{l}\text { Virus-cell fusion } \\
\text { Viral inactivation } \\
\text { Viral envelope }\end{array}$ & $\begin{array}{l}\text { Morimoto et al., 1991; Murakami } \\
\text { et al., 1991; Yasin et al., } 2000\end{array}$ \\
\hline$\theta$-defensin & Homo sapiens & Human & $\begin{array}{l}\text { HIV } \\
\text { HSV }\end{array}$ & $\begin{array}{l}\text { Binds glycosylated gp120 } \\
\text { Binds gB and blocks viral } \\
\text { attachment }\end{array}$ & $\begin{array}{l}\text { Cole et al., 2002; Yasin et al., } \\
2004\end{array}$ \\
\hline \multicolumn{6}{|l|}{ ANIMAL HEALTH } \\
\hline $\begin{array}{l}\text { Cecropin B } \\
\text { CF17 }\end{array}$ & Hyalophora cecropia & $\begin{array}{l}\text { Insect } \\
\text { Synthetic }\end{array}$ & $\begin{array}{l}\text { IHNV } \\
\text { VHSV } \\
\text { SHRV } \\
\text { IPNV }\end{array}$ & $\begin{array}{l}\text { Disrupts the viral envelope } \\
\text { Disintegrates the viral } \\
\text { capsids }\end{array}$ & Chiou et al., 2002 \\
\hline $\begin{array}{l}\text { Epinecidin-1 } \\
\text { TH 1-5 } \\
\text { cSALF }\end{array}$ & $\begin{array}{l}\text { Oreochromis } \\
\text { mossambicus } \\
\text { Penaeus monodon }\end{array}$ & $\begin{array}{l}\text { Fish } \\
\text { Shrimp }\end{array}$ & NNV & $\begin{array}{l}\text { Agglutinates NNV virions } \\
\text { into clump }\end{array}$ & Chia et al., 2010 \\
\hline \multicolumn{6}{|l|}{ AGRICULTURE } \\
\hline PAP & Phytolacca americana & Plant & $\begin{array}{l}\text { TMV } \\
\text { CMV } \\
\text { CaMV }\end{array}$ & $\begin{array}{l}\text { Inhibit viral protein } \\
\text { synthesis }\end{array}$ & Chen et al., 1991 \\
\hline Indolicidin & Bos taurus & $\begin{array}{l}\text { Bovine } \\
\text { neutrophils }\end{array}$ & TMV & Unknown & Bhargava et al., 2007 \\
\hline Peptamine & $\begin{array}{l}\text { Pseudomonas } \\
\text { chlororaphis } 06\end{array}$ & Bacteria & TMV & Unknown & Park et al., 2012 \\
\hline Analogs of melittin & Apis mellifera & Synthetic & TMV & Cellular target & Marcos et al., 1995 \\
\hline
\end{tabular}

Adapted from (Jenssen et al., 2006); -Not reported. AdV, adenovirus; CaMV, cauliflower mosaic virus; CMV, cytomegalovirus; HBV, hepatitis B virus; HCMV, human cytomegalovirus; HCV, hepatitis C virus; HIV, Human immunodeficiency virus; HSV, hermpes simplex virus; IAV, influenza; IHNV, infectious haematopoietic necrosis virus; IPNV, infectious pancreatic necrosis virus; JV, junin virus; NNV, nervous necrosis virus; PVYO, potato virus YO; SHRV, snakehead rhabdovirus; TMV, tobacco mosaic virus; VHSV, viral hemorrhagic septicemia; VSV, vesicular stomatitis virus; VSV, vesicular stomatitis virus.

peptide has been reported to deactivate HSV-1 and HSV-2, CMV, vesicular stomatitis virus, influenza virus and human respiratory adenovirus type-5 (AdV-5) (Daher et al., 1986; Yasin et al., 2004). Treatment with this peptide has shown a decrease of adenoviral infection by more than 95\% in 293 cells infected with AdV-5) (Bastian and Schafer, 2001). $\theta$-defensins are circular octadecapeptides with two antiparallel $\beta$-sheets that are bridged by a tri-disulfide ladder and connected by two $\beta$-turns (Yasin et al., 


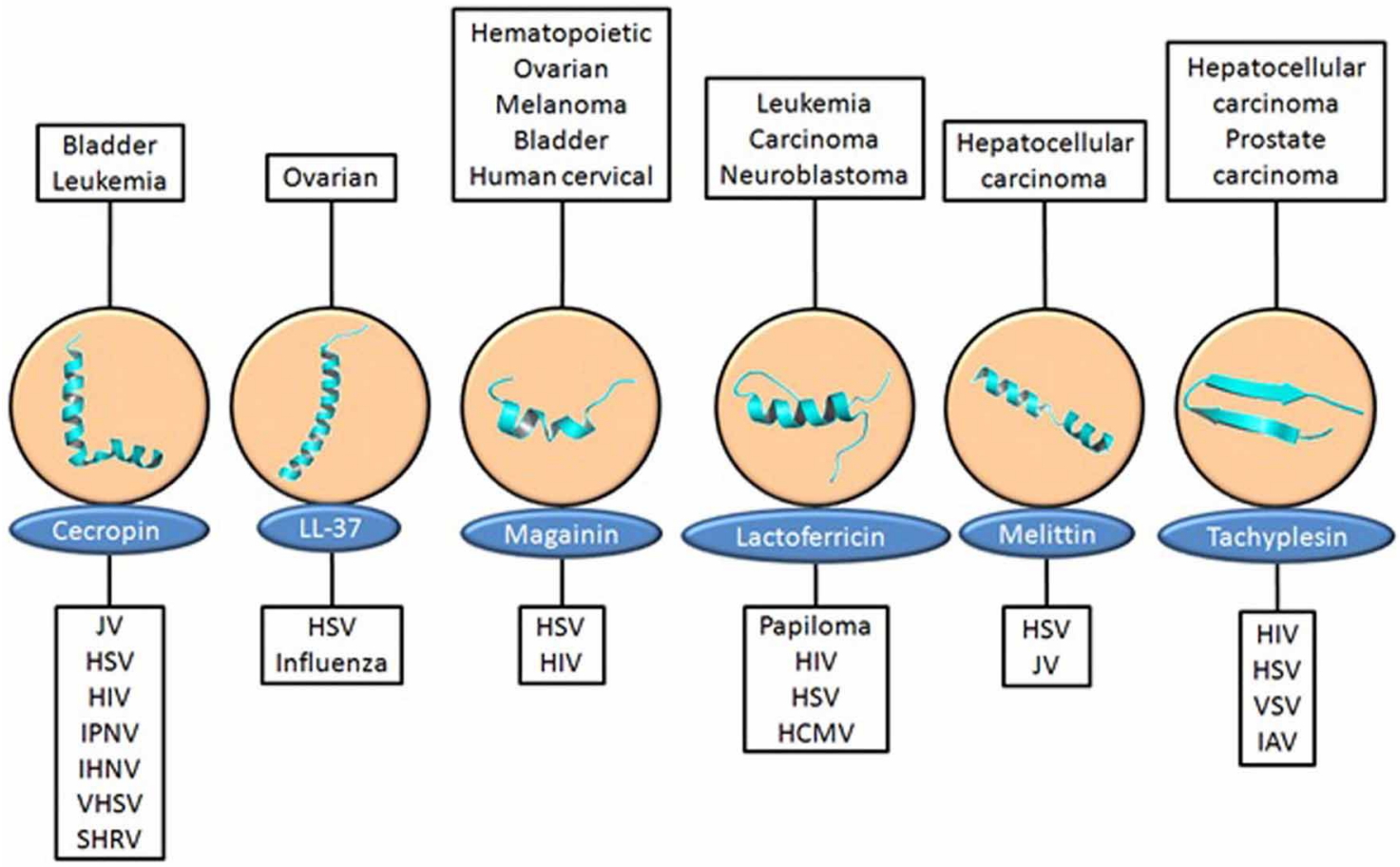

FIGURE 2 | Promiscuous cationic peptides with antitumor and antiviral activities. Each promiscuous peptide and their various tumors against which present cytotoxic activity (top) and viruses against which present antiviral activity (bottom). \#PDB from left to right, 2IGR, 2K6O, 2LSA, 1Z6V, 2MLT, 1WO1. HCMV, human

cytomegalovirus; HIV, Human immunodeficiency virus; HSV, herpes simplex virus; IAV, influenza; IHNV, infectious hematopoietic necrosis virus; IPNV, infectious pancreatic necrosis virus; JV, Junin virus; SHRV, snakehead rhabdovirus; VHSV, viral hemorrhagic septicemia; VSV, vesicular stomatitis virus.
2004). This class of peptide has been reported to be miniature lectins that bind to the protein gp120 of human immunodeficiency virus type 1 (HIV-1) with high affinity, blocking its entry into the host cell (Figure 3) (Munk et al., 2003).

The promiscuous peptide LfcinB (Figure 2) has shown inhibition against many viruses such as HIV-1, HSV-1, and HSV-2, human cytomegalovirus (HCMV), respiratory syncytial virus, hepatitis $\mathrm{B}$ and $\mathrm{C}$ viruses (HBV and $\mathrm{HCV}$, respectively), adenovirus, and rotavirus (Van Der Strate et al., 2001; Andersen et al., 2003). The activity of Lfcin has been claimed to be attributed to the affinity of this peptide for carbohydrates, which are viral binding sites on the cell membrane, such as heparin sulfate (HS) and glycosaminoglycans (GAGs), thereby blocking viral entry (Andersen et al., 2003). The antiviral activity of LfcinB and LfcinH (human lactoferricin) against HSV has been verified with the ability of this peptide to interact with HS and block viral entry. It has been found that the positive net charges of the peptides are critical for affinity with HS which is due to the many negatively-charged sulfate groups present in the molecule (Jenssen et al., 2004). Together with Lfcin, the peptides human $\alpha$-defensin, LL-37 and magainin have also been reported to bind to GAGs in order to perform their respective activities (Figure 3 ) (Jenssen et al., 2006). It has also been shown that a stabilized secondary structure is important for antiviral activity for both LfcinB and LfcinH (human lactoferricin). The higher potency of LfcinB against some viruses compared to LfcinH is attributed to the $\beta$-sheet conformation of LfcinB in solution compared with the $\alpha$-helical structures of LfcinH (Jenssen et al., 2004).

Lactoferrin (Lf), the protein from which the peptide Lfcin is derived, shows antiviral activity against a number of viruses as much as seven times greater than that of Lfcin, proposing that either the size of the molecule is important or that other regions of LF contribute to the antiviral activity (Andersen et al., 2003; Gifford et al., 2005). The positive charge of Lf was found to be important for antiviral activity against human HCMV (Valenti and Antonini, 2005). When negatively-charged groups were added to Lf by succinylation, the antiviral potency was mostly decreased, whereas the addition of positive charges to Lf through amination of the protein resulted in increased antiHCMV activity (Harmsen et al., 1995). On the other hand, when tested against HIV-1, a 4-fold stronger antiviral effect of Lf was observed when negatively-charged groups were added (Harmsen et al., 1995). The proposed mechanism of action for anti-HIV activity was that Lf and the charged-modified protein bind strongly to the V3 loop of the gp120 envelope protein, increasing the net negative electric charge of viral particles, and resulting in inhibition of virus-cell fusion and entry of the virus into cells (Puddu et al., 1998) Another report of direct interaction of viral proteins with Lf has been observed in HCV. Inhibition of virus-cell adsorption was verified in human hepatocytes $\mathrm{PH} 5 \mathrm{CH} 8$ when bLf was mixed prior to the viral infection in serum containing $\mathrm{HCV}$, and no antiviral activity of bLf was observed after 


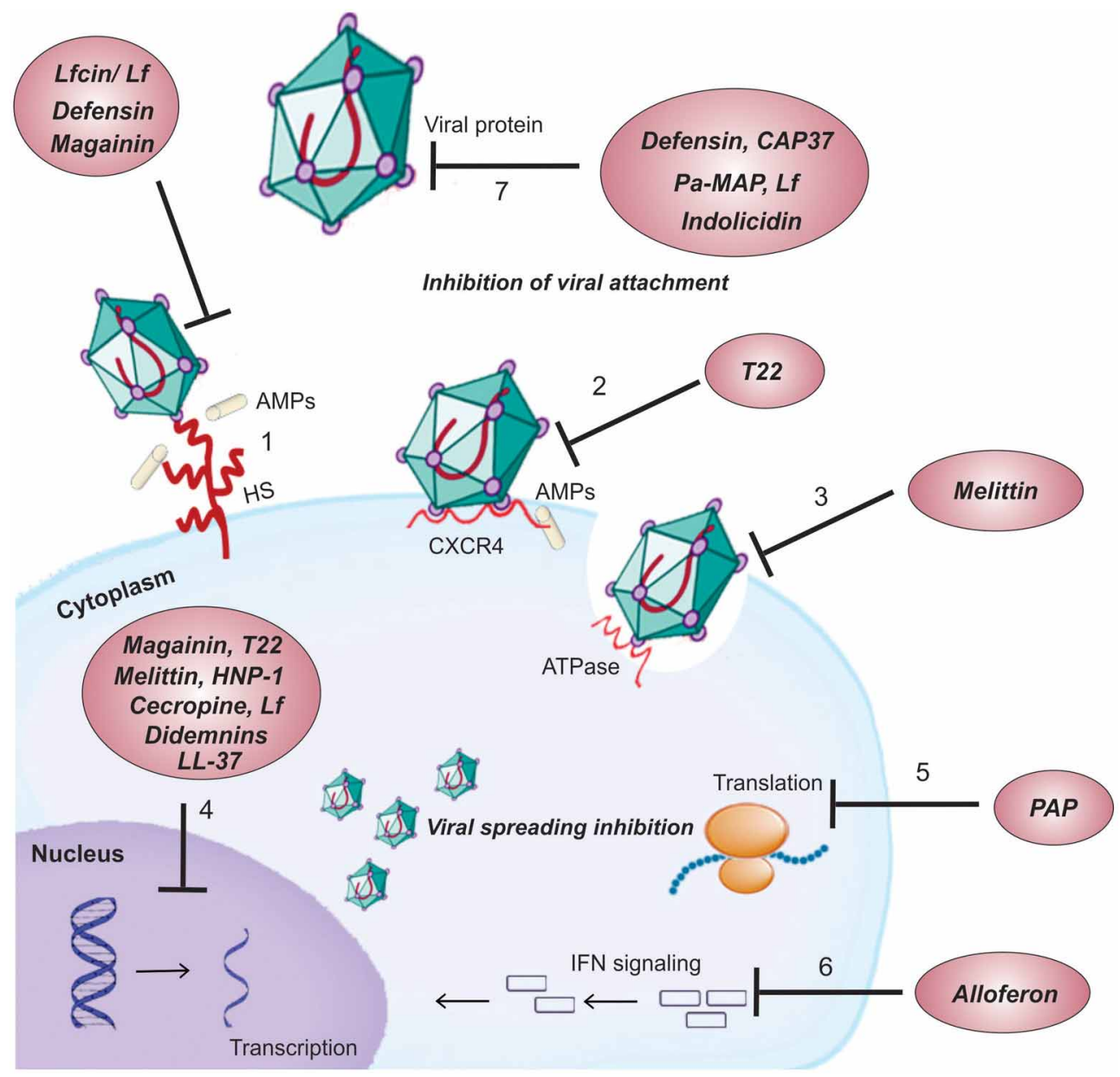

FIGURE 3 | Mechanisms of action of cationic antiviral peptides. Cell surface targets: (1) Interaction of peptides with different glycosaminoglycan (e.g., HS) present on the cell surface competing with the virus for cellular binding sites. (2) Blocking of viral entry into the cell by binding the peptide to viral CXCR4co-receptor required for its entry. (3) Suppression of cell fusion by interfering with the activity of ATPase protein. Intracellular targets: (4) Suppression viral gene expression. (5) Inhibition of peptide chain elongation by inactivating the ribosome. (6) Activation of an immune modulatory pathway by induction of NK and IFN. Viral protein targets: (7) Binding of peptides to viral proteins causing inhibition of adsorption/virus-cell fusion. internalization of HCV in human hepatocytes (Ikeda et al., 1998). This activity has been reported to be involved in the ability of hLF and bLF to bind to E1 and E2 proteins of the viral envelope, indicating that neutralization occurs in order to prevent the adsorption of HCV in the hepatocytes (Yi et al., 1997). During in vivo experiments, bLF protected the host mice against infection of the mouse cytomegalovirus (MCMV) when the peptide was injected prior to the viral infection, but failed to protect the mice when the injection was performed after MCMV infection (Shimizu et al., 1996).

Another human-derived peptide which targets envelope/membrane is the promiscuous peptide CAP37, first isolated from the granule fractions of human PMNs. It has been shown to have potent activity against viruses (HSV-1 and Adenovirus), bacteria (Pseudomonas aeruginosa, E. coli, Salmonella typhimurium, Staphylococcus aureus, and Enterococcus faecalis), and fungi (Candida albicans). Its structure/function differs from the others peptides here mentioned. It is known that cystine residues forming intramolecular disulfide bridges are necessary for the antibacterial function of CAP37 but are not required for its antiviral activity, which has been suggested to be involved in the rupture of the envelope and/or capsid (Gordon et al., 2009).

The promiscuous peptide LL-37 (Figure 2) differs from the above defensins, Lfcin, and bLf in its mechanism of action. Instead of targeting cell surface molecules, it inhibits viral spreading by inactivating intracellular targets (Figure 3). LL-37 have nuclear localization signals and have been related to interact with DNA, directly influencing viral nucleic acid synthesis (Sandgren et al., 2004). The same is applied to indolicidin, a peptide isolated from the cytoplasmic granules of bovine neutrophils (Hsu et al., 2005). However, besides its DNA-binding ability, it has also shown activity against HIV and HSV through a membranemediated antiviral mechanism (Robinson et al., 1998).

Marine organisms are also included as a source of cationic antiviral peptides (Table 2). One example is the promiscuous 
peptide Pa-MAP isolated from the fish Pleuronectes americanus, which beyond having shown broad antimicrobial activity against bacteria (E. coli and S. aureus), fungi (Candida parapsilosis, Trichophyton mentagrophytes, and Trichophyton rubrum) and tumor cells in culture (CACO-2, MCF-7, and HCT-116), also has activity against viruses (HSV-1 and HSV-2). The antiviral mechanism of this peptide has been suggested to involve its interaction with the viral envelope (Migliolo et al., 2012; Teixeira et al., 2013).

A group of cationic antiviral peptides from vertebrate and invertebrate sources has been tested by Carriel-Gomes et al. (2007). This study has shown in vitro evaluation of the cytotoxicity and antiviral activity of nine AMPs against many human viruses (Carriel-Gomes et al., 2007). They were PW-2 recombinant, tachyplesin-1 from limulid, gomesin from spider, clavanin A from tunicate, magainin from frog, synthetic HCTF, penaeidin3 and ALF from shrimp, and mytilin A from mussel. These peptides have different structures, origins and antiviral activities against HSV-1, AdV-5, and rotavirus SA11 (RV-SA11). All evaluated peptides were cytotoxic and had antiviral activities in different degrees. The peptides PW-2, ALF and penaeidin-3 exhibited higher antiviral activity against HSV-1. The peptides ALF and clavanin A showed significant antiviral activity against AdV-5 with clavanin A exhibiting a greater inhibition of viral replication (Carriel-Gomes et al., 2007).

\section{ANTIVIRAL PEPTIDES DRUGS APPLIED TO ANIMAL HEALTH}

Several studies have reported the efficiency of AMPs active against viruses that cause diseases in humans. However, few studies have demonstrated the potential application of these peptides in animal health. Here we present studies showing the application of antiviral peptides in aquaculture. Viral diseases have emerged as the most serious infectious problems for the fish aquacultural industry, and studies have found promising cationic antivirus peptides being used against several viruses including rhabdoviruses such as viral hemorrhagic septicemia virus (VHSV) and infectious hematopoietic necrosis virus (IHNV), which are responsible for the greatest losses in aquaculture production.

The native cecropine B and its synthetic analog CF17, have demonstrated activity against major viral fish pathogens such as infectious hematopoietic necrosis virus (IHNV), viral hemorrhagic septicemia virus (VHSV), snakehead rhabdovirus (SHRV) and infectious pancreatic necrosis virus (IPNV). The mechanism of action involved in the inhibition of viral replication by peptides is related to the direct disruption of the viral envelop and the disintegration of the viral capsids (Chiou et al., 2002).

Chia and collaborators reported that both peptides tilapia hepcidin 1-5 (TH 1-5) and cyclic shrimp anti-lipopolysaccharide factor (cSALF) exhibited noticeable antiviral activity in vitro against nervous necrosis virus (NNV), a virus that has caused mass mortality of numerous marine fish species at their larval stage. The antiviral mechanism of both peptides was by agglutinating NNV virions into clump and preventing viral entry into the cells (Chia et al., 2010). Together with hepcidin 1-5, the peptide hapcidin 1 has also shown antiviral activity in vivo against NNV in the Japanese rice fish medaka (Oryzias latipes). Pre-treatment, cotreatment or post-treatment with epinecidin-1 or hepcidin 1-5 has shown to be effective in promoting a significant increase in medaka survival when infected with NNV (Wang et al., 2010a).

Falco and collaborators (2009) have reviewed the role of many AMPs as antiviral agents in the fish farm industry. Among these molecules there are pleurocidin and the HNP1. Pleurocidin MDPle, isolated from the Mud dab fish (Limanda limanda), has presented antiviral properties against VHSV. It is likely that it disrupts the viral membrane under the same mechanisms adopted for its antibacterial activity (Falco et al., 2009). The HNP1 is a defensin that has demonstrated antiviral effects against the same virus as MDPle. It has been claimed that, as belonging to the class of defensins, HNP1 can deactivate the enveloped virus by interacting with GAGs present on the viral surface, altering the ability of these glycoproteins to bind to their receptors at the target cells. Moreover, this peptide has also been shown to stimulate the immune modulatory system of infected fish cells by modulating IFN-related mechanisms (Falco et al., 2007, 2009).

\section{ANTIVIRAL PEPTIDE DRUGS APPLIED TO AGRICULTURE}

Cationic antivirus peptides may also be applied to plant protection against viruses that cause diseases in crops. Among the various symptoms of viral infections in plants, stunting, mosaic patterns, yellowing, leaf rolling, ring spot, necrosis, wilting, and other developmental abnormalities can be observed (Hull, 2002). These symptoms consequently cause a decrease in production leading to economic losses. Strategies to combat viral diseases in plants are usually directed to the prevention or reduction of infection which may have, however, adverse effects on human health and the environment. Therefore, AMPs have become promising alternatives for protecting crops against viral diseases while simultaneously protecting human health and the environment.

A cyclic peptide of 7 amino acid residues called peptamine from Pseudomonas chlororaphis O6 has shown antiviral activity against the tobacco mosaic virus (TMV). Antiviral bioassays of tobacco plants suppressed 95\% of TMV disease. The mode of action by which peptamine suppresses the disease is still unknown, but it has been speculated that this peptide may induce systemic resistance against TMV (Park et al., 2012). The peptide PAP, a ribosome inactivating protein (RIP) isolated from Phytolacca americana, was highly effective in inhibiting the formation of local lesions caused by TMV on tobacco leaves (Taylor et al., 1994). RIPs are known to cause damage to ribosomes by removing adenine residues from $28 \mathrm{~S}$ rRNA through an $\mathrm{N}$ glycosidase activity, and the removal of this base prevents binding of the elongation factor 2 (EF-2), consequently stoping the synthesis of proteins (Kaur et al., 2011). Another cationic antiviral with activity against TMV is subK7I, a synthetic analog of melittin. This peptide has sequence and structural similarity to an essential domain of the TMV coat protein and was found to possess highly specific antiviral activity. Bioassays of tobacco leaves upon addition of the analog to the solution before inoculation of the virus has demonstrated a reduction of more than $90 \%$ of infectivity of TMV with dependent doses (Marcos et al., 1995).

Tripathi and colleagues isolated a small antiviral peptide of $5.57 \mathrm{kDa}$ called potide- $\mathrm{G}$ from potato tubers resistant to Potato Virus Y (PVY). Results of real-time PCR showed that the application of $10 \mu \mathrm{g}$ of purified potide-G was sufficient to reduce 
virus accumulation by $50 \%$ on average from the PVY infection in susceptible "Winter Valley" cultivars. The authors have reported that this peptide isolated from resistant potatoes offers new opportunities for the development of new biological pesticides against plant viruses (Tripathi et al., 2006).

\section{PRODUCTION OF CATIONIC ANTITUMOR AND ANTIVIRAL PEPTIDES}

While peptides have great potential for use in antitumor drugs, there are some limitations that need to be addressed. It is wellknown that they can be used in a number of different ways in treating cancer such as vaccines, hormones, tumor targeting with cytotoxic drugs and radioisotopes, and anti-angiogenic peptides (Thundimadathil, 2012). Currently, there are about 60 approved peptide drugs on the market and it is expected to reach an estimated $\$ 12$ billion USD in sales by the end of 2013 (Pichereau and Allary, 2005). All of these investments have resulted in more than 100 peptide-based drugs which are already available on the global market, representing about $1.5 \%$ of all drug sales (Lax, 2010; Craik et al., 2013). Out of four peptide drugs on the market which have reached global sales over $\$ 1$ billion USD, three peptides are used in treating cancer directly or in the treatment of episodes associated with certain tumors: leuprolide acetate (Lupron; \$2.12 billion), goserelin acetate (Zoladex; \$1.14 billion), and octreotide acetate (Sandostatin; $\$ 1.12$ billion) (Reichert et al., 2010; Thundimadathil, 2012). Mendoza and colleagues have summarized approximately 30 peptides which were discovered/developed as peptide-based anticancer drugs in order to provide foundations for therapies (Mendoza et al., 2005).

However, when it comes to the market of AMPs as antitumor drugs, the scenario is much different. Although over 1000 potential therapeutic AMPs have been isolated and characterized from different sources, only limited success has been achieved in clinical trials (Hu et al., 2011).

There are currently only around ten AMPs in either preclinical or clinical trial phases (Fox, 2013) and few of these present antitumor activity. Their major limitations are the poor bioavailability due to their instability and insolubility related to the intrinsic physicochemical properties, potential toxicity to host cells, tissue distribution, poor pharmacokinetic issues, and the cost of large scale production (Rotem and Mor, 2009; Hu et al., 2011). Despite these disadvantages, antitumor peptides have potential due to their high specificity and potency against malignant cells. Therefore, numerous studies have been performed in order to improve their bioavailability and reduce their cost of production. Much effort has been put into the mimicry of antitumor peptides to alter their features in order to achieve robustness and safety. These approaches have become important and promising for improving the therapeutic potential of antitumor peptides (Rotem and Mor, 2009).

HDP mimicry has been performed by constructing oligomers of acyl-lysyl and/or lysyl-acyl-lysyl (OAKs), which has turned out to be the first designed system to show antitumor potential in vivo. This system was able to translocate across the membrane and interact with multiple intracellular targets, including mitochondria, especially the inner membrane which contains a relatively high portion of negatively-charged phospholipids that might mediate interactions with these HDPs. Moreover, it was associated with an improved toxicity profile when compared to doxorubicin, an anthracycline antibiotic used in chemotherapy. It has also been observed that local administration of both OAK and doxorubicin resulted in a complete disappearance of tumors in $50 \%$ of treated mice, while in the remaining $50 \%$ tumors were minuscule, thereby suggesting that the synergic effect of this therapy was both potent and well tolerated. The OAK might also damage lysosome structure and/or interfere with the function of 50 hydrolases that normally process the cell's major macromolecules (Held-Kuznetsov et al., 2009).

In another study, sequence optimization and modification based on natural peptide sequences and traits was performed and it has shown that the system G(IIKK)nI-NH 2 (being $n=3-4$ ) was effective against HeLa and HL60 cancer cell lines with 50\% growth inhibition concentrations (Hu et al., 2011). Mai and colleagues have designed a novel antitumor peptide, DP1, derived from a synthetic AMP that significantly induces apoptosis in solid tumors by local injection. It was composed of a protein transduction domain (PTD), PTD-5, fused to the AMP KLAKLAK, an antimicrobial apoptosis-inducing peptide that upon internalization causes mitochondrial swelling and disruption of the mitochondrial membrane leading to apoptosis (Mai et al., 2001; Thundimadathil, 2012).

Rational design of novel peptides has also been performed to create six analogs of temporin-1CEa, a naturally occurring $\alpha$ helical and amphipathic AMP derived from skin secretions of the Chinese brown frog Rana chensinensis (Yang et al., 2013). These analogs were synthesized with either increased cationicity or increased/decreased hydrophobicity generally by substituting neutral and acidic amino acids with lysine or leucine residues on the polar face and non-polar face of the $\alpha$-helix in order to evaluate the correlation between anticancer activity and physical properties of these peptides. All peptides showed potent anticancer activities against three cancer cell lines (MCF-7, Bcap-37, and MDA-MB-231). This study has suggested that the strategy of increasing the cationicity and keeping moderate hydrophobicity of naturally occurring AMPs is suitable to improve their cytotoxicity against tumor cells and decrease their hemolytic activity (Yang et al., 2013).

Synthetic links between two functional domains, an AMP (KLAKLAKKLAKLA K) and the isoDGR, (isoAsp-Gly-Arg), a derivative of a targeted delivery tool, was performed to construct a novel antitumor peptide. It was shown that this novel construction can selectively kill CD13 ${ }^{-} / \alpha_{\nu} \beta_{3+}$ breast cancer cells in both in vitro and in vivo experiments. The mechanism of action was claimed to inhibit angiogenesis by binding to $\alpha_{v} \beta_{3}+$ which is upregulated on tumor cells and tumor endothelial cells (Hou et al., 2013).

These studies strongly suggest that the peptidomimetics is a potent tool for developing new antitumor peptides. Moreover, these molecules may have their potential increased when it functions as an adjuvant therapy in conjunction with radiotherapy, chemotherapy, or surgical procedures.

When antiviral therapy is considered, the major barriers to the development and use of effective therapy are the current expensive approaches to impairing the completion of the viral growth cycle in the infected cell without being toxic to the surrounding normal cells, and diagnosing the viral disease before it is too 
late for effective therapy. It has also been claimed that the reason for the lack of progress in antiviral therapy is the selectivity, since the viruses are functionally incorporated into the host cells, and therefore it is difficult to select a proper tag (Kinchington et al., 1995; Abonyi et al., 2009). Furthermore, a relevant barrier is applied to the market of antivirus drugs, which concentrate efforts on a few viruses. It is known that out of 60 antiviral drugs that have thus far been approved by the US Food and Drug Administration (FDA), almost half of them target HIV1 with the remaining half used for the treatment of $\mathrm{HBV}$ and HCV infections, HSV, CMV, varicella-zoster virus (VZV), and influenza (IAV) (De Clerq, 2008; Findlay et al., 2013). There are currently 15 peptide-based strategies against viruses in different stages of clinical trials as candidates for therapeutic drugs against many viruses (Thakur et al., 2012). However, none are cationic antiviral peptides, although reports of their high activity are exciting enough to include them as potential candidates, as is the case of alloferon. It has been shown that preventive and/or therapeutic administration of alloferon essentially increased the survival rate and suppressed virus reproduction in mice intracerebrally infected with HSV-2. Alloferon-based therapy of HSV, $\mathrm{HBV}$, and HCV infections is now under extensive preclinical study (Chernysh et al., 2002).

Synthetic analogs of several naturally occurring AMPs have been made in attempt to identify important structural features contributing to their antiviral activity as well as to optimize these molecules in order to develop the shortest, cheapest, most stable and functional molecules at lower concentrations (Jenssen et al., 2006). Recently, the first antivirus peptide prediction method, based on the collected peptides which were experimentally proven for antiviral activity, was developed and named AVPpred (Thakur et al., 2012). This method is specific for antivirus peptides, where 25 physicochemical properties to develop antivirus peptide-physico models, amino acid composition, and sequence alignment implementing BLASTP algorithms for prediction of AVPs were used.

\section{HETEROLOGOUS PRODUCTION OF ANTITUMOR AND ANTIVIRAL CATIONIC PEPTIDES}

Beyond the use of peptide mimicry to develop synthetic peptides, the advance in the use of heterologous systems for production of cationic peptides has been a promising alternative. Many groups have been performing recombinant technology in order to optimize the production yield of cationic peptides using animal cells (Brocal et al., 2006), yeast (Wang et al., 2009b), plant (Lee et al., 2011), and bacteria systems (Wang et al., 2011).

For instance, the expression and purification of the recombinant human $\alpha$-defensin 5 has been performed in Pichia pastoris, and it has been reported that this peptide was functionally expressed and it showed in vitro activity to block human papillomavirus infection (Wang et al., 2009b). The housefly cecropin peptide has also been expressed in this organism, however, neither antiviral nor antitumor activities have been tested in this specific system (Jin et al., 2006). The lack of both activity could also be observed for the expression of the peptide pleurocidin, which has been expressed in both yeast (Burrowes et al., 2005) and fish cell lines (Brocal et al., 2006), although only in the latter case antibacterial activity was tested.

The concept of plant-made biopharmaceuticals has also been lately explored for the expression of antiviral cationic peptides. For example, the peptide retrocyclin, an important AMP which can be used as therapeutic agent against HIV-1 viral infections, have been expressed and characterized in tobacco chloroplasts genome, and its antiviral activity was confirmed against TMV infection (Lee et al., 2011). The peptide cecropin was also expressed in both camelina (Camelina sativa) (Zakharchenko et al., 2013) and tomato (Solanum lycopersicum) (Jan et al., 2010). Nevertheless, in these studies the tests performed did not include antiviral or antitumor activities.

The most common organism for construction of heterologous expression systems is bacteria, and E. coli is the most used (Parachin et al., 2012). This bacterium has been used for expression of cecropin (Liang et al., 2006), lactoferricin (Luo et al., 2007), human $\alpha$ and $\beta$ defensins (Wang et al., 2010b), buforin (Wang et al., 2011), indolicin (Morin et al., 2006), and LL-37 (Moon et al., 2006). Two different systems for expression of cecropin, one fused to enterokinase (Xu et al., 2007a) and other hybrid system fused to ubiquitin (Xu et al., 2007b) were constructed, and both systems were active against Gram-positive and negative bacteria, and fungi. Another two hybrid systems have also been constructed to actively express the peptide lactoferricin (Kim et al., 2006; Feng et al., 2011). Furthermore, many bioactive human defensin have been successfully expressed in $E$. coli such as the human $\alpha$-defensin 6 , which showed to inhibit HSV-2 infection (Wang et al., 2010b), the $\beta$-defensin 5 and 6 (Huang et al., 2008 ), the $\beta$-defensin 26 and 27 (Huang et al., 2009), $\beta$-defensin 2 (Zhong et al., 2006), and $\beta$-defensin 4 (Xu et al., 2006; Li et al., 2010).

As shown above, many studies have shown that the heterologous expression of cationic peptides is feasible, and in many cases, depending on their size and structure, is a better alternative for production of pharmaceuticals than the synthetic synthesis (Parachin et al., 2012). However, none of the studies cited above have optimized the large-scale production of the peptides expressed. Doubtless it is important to mention that many efforts have been made to efficiently develop or improve the costeffective methodology (e.g., new expression systems and optimized fermentation processes) for production of AMPs, as well as to overcome barriers involving both recombinant technology processes and the economic scenario of biotechnology and pharmaceutical companies in order to change the drug-development current scenario.

\section{NANOFORMULATION AS DRUG-DELIVERY SYSTEM}

In order to overcome the restraints to the use of cationic peptides described above, nanoformulation techniques have emerged as a potent biological tool to improve the delivery and stability and of these molecules.

The primary goals of drug delivery for cancer therapy is to improve the therapeutic index of anticancer drugs by increasing the amount of drug delivered to the tumor site and decreasing its exposure to healthy tissues (McDaniel et al., 2010). Several microencapsulation technologies have been developed for use 
in the pharmaceutical industry, such as hydrogels, liposomes, nanoemulsions, and nanoparticles (Onwulata, 2012). Therefore, the development and improvement of nanoparticles have shown great promise to overcome the delivery barriers of pharmaceuticals (Zhang et al., 2012).

Recently Wang and Zhang (2013) encapsulated a CPAP, a dose-dependent antiproliferation peptide and inducer of the post-G1 cell cycle arrest in gastric cancer cells. Two methods were used: complex coacervation (edible alginate, $\mathrm{CaCl} 2$ and chitosan involved) to perform a microencapsulation of CPAP, and ionotropic gelation (edible chitosan and sodium tripolyphosphate involved) to perform a nanoencapsulation process. The former refers to the phase separation of a liquid precipitate/phase when solutions of two hydrophilic colloids are mixed under suitable conditions, and the latter is based on the ability of polyelectrolyte counter ions to cross link to form hydrogels (Wang and Zhang, 2013). Their results demonstrated that the encapsulation efficiency of microencapsulation $(74.5 \%)$ is much greater than that of nanoencapsulation $(30.1 \%)$, but their polypeptides contents are similar (12.7 vs. $12.3 \%)$. The in vitro release tests revealed that CPAP was well-preserved against gastric enzymatic degradation after micro/nanoencapsulation and the slowly-controlled release in the intestine could be achieved. Although further in vivo studies are required to verify these findings, this study has provided a basis for the development of encapsulated antitumor peptides (Wang and Zhang, 2013).

Another study has performed encapsulation of an antitumor peptide in order to develop an effective gene-modified tumor cell vaccine. In this study, the gene of interleukin-27 (IL-27), a novel IL-6/IL-12 family cytokine, was transfected in LL/2 (Lewis lung cancer cell) by using a cationic liposome. This resultant tumor cell vaccine then containing both tumor associated antigen (TAA) of LL/2 cells and secreted mIL-27 (mouseIL-27) at a relative high level, could induce protective antitumor immunity in mice, which was claimed to be an attribute of high-cytokine production achieved by the liposome-DNA complex. It was also observed that LL/2-mIL-27 cell vaccine up-regulated IFN- $\gamma$ in serum and improved local CD4+ and CD8+ T cell infiltration in mice. This study shows an important and promising strategy for AMP-based therapeutic approach against tumors (Zhang et al., 2013b).

Regarding cationic antiviral peptides, a nanoformulation technique has also been studied as a potent bio-tool to improve their delivery and stability. Nanoformulation of the amphiphatic $\alpha$ helical peptide $\mathrm{p} 41$, a positively-charged analog of C5A peptide derived from the HCV protein, was performed to treat $\mathrm{HIV} / \mathrm{HCV}$ co-infection. The cationic antiviral peptide was incorporated into anionic poly (amino acid)-based block copolymers prepared via eletrostetic coupling. The nanocomplexes were ca. $35 \mathrm{~nm}$ in size, stable at physiological $\mathrm{pH}$ and ionic strength. The in vitro antiviral activity against both HCV and HIV was retained and their intrinsic cytotoxicity was attenuated. The in vivo APN were able to decrease the viral load in mice transplanted with human lymphocytes and HIV-1-infected. Overall, these findings indicate the potential of these formulations for stabilization and delivery of antiviral peptides while maintaining their functional activity (Zhang et al., 2013a).

\section{CONCLUDING REMARKS}

Many natural cationic peptides from the immense biodiversity of several groups of organisms have been isolated and have demonstrated great potential as antiviral and antitumor agents. Furthermore, the development of novel synthetic analogs of these natural molecules has been an important biological tool for enhancing their activities and facilitating the screening process for new natural AMPs. Studies on antitumor and/or antiviral AMPs have demonstrated that these molecules work as excellent therapeutic agents and even lead to greater success when combined with traditional treatments. The number of antitumor and/or antiviral AMPs has been increasing and is expected to lead to a change in their current scenario, from their entry into clinical trial to their availability on the market. A crucial step for this change to occur is to continue researching and identifying their mechanisms of action and to discover new targets, followed by studies on developing new potential delivery systems.

\section{REFERENCES}

Abonyi, D. O., Adikwu, M. U., Esimone, C. O., and Ibezim, E. C. (2009). Plants as sources of antiviral agents. Afr. J. Biotechnol. 8, 3989-3994.

Aboudy, Y., Mendelson, E., Shalit, I., Bessalle, R., and Fridkin, M. (1994). Activity of two synthetic amphiphilic peptides and magainin-2 against herpes simplex virus types 1 and 2. Int. J. Pept. Protein Res. 43, 573-582. doi: 10.1111/j.13993011.1994.tb00559.x

Alberts, A. W., Chen, J., Kuron, G., Hunt, V., Huff, J., Hoffman, C., et al. (1980). Mevinolin: a highly potent competitive inhibitor of hydroxymethylglutarylcoenzyme A reductase and a cholesterol-lowering agent. Proc. Natl. Acad. Sci. U.S.A. 77, 3957-3961. doi: 10.1073/pnas.77.7.3957

Albiol Matanic, V. C., and Castilla, V. (2004). Antiviral activity of antimicrobial cationic peptides against Junin virus and herpes simplex virus. Int. J. Antimicrob. Agents 23, 382-389. doi: 10.1016/j.ijantimicag.2003.07.022

Andersen, J. H., Jenssen, H., and Gutteberg, T. J. (2003). Lactoferrin and lactoferricin inhibit Herpes simplex 1 and 2 infection and exhibit synergy when combined with acyclovir. Antivir. Res. 58, 209-215. doi: 10.1016/S01663542(02)00214-0

Andersen, J. H., Osbakk, S. A., Vorland, L. H., Traavik, T., and Gutteberg, T. J. (2001). Lactoferrin and cyclic lactoferricin inhibit the entry of human cytomegalovirus into human fibroblasts. Antivir. Res. 51, 141-149. doi: 10.1016/S0166-3542(01)00146-2

Aneiros, A., and Garateix, A. (2004). Bioactive peptides from marine sources: pharmacological properties and isolation procedures. J. Chromatogr. B Analyt. Technol. Biomed. Life Sci. 803, 41-53. doi: 10.1016/j.jchromb.2003. 11.005

Bai, R., Pettit, G. R., and Hamel, E. (1990). Dolastatin 10, a powerful cytostatic peptide derived from a marine animal. Inhibition of tubulin polymerization mediated through the vinca alkaloid binding domain. Biochem. Pharmacol. 39, 1941-1949. doi: 10.1016/0006-2952(90)90613-P

Barlow, P. G., Svoboda, P., Mackellar, A., Nash, A. A., York, I. A., Pohl, J., et al. (2011). Antiviral activity and increased host defense against influenza infection elicited by the human cathelicidin LL-37. PLOS ONE 6:e25333. doi: 10.1371/journal.pone.0025333

Barra, D., and Simmaco, M. (1995). Amphibian skin: a promising resource for antimicrobial peptides. Trends Biotechnol. 13, 205-209. doi: 10.1016/S01677799(00)88947-7

Bastian, A., and Schafer, H. (2001). Human alpha-defensin 1 (HNP-1) inhibits adenoviral infection in vitro. Regul. Pept. 101, 157-161. doi: 10.1016/S01670115(01)00282-8

Belaid, A., Aouni, M., Khelifa, R., Trabelsi, A., Jemmali, M., and Hani, K. (2002). In vitro antiviral activity of dermaseptins against herpes simplex virus type 1 . J. Med. Virol. 66, 229-234. doi: 10.1002/jmv.2134

Bevins, C. L., and Zasloff, M. (1990). Peptides from frog skin. Annu. Rev. Biochem. 59, 395-414. doi: 10.1146/annurev.bi.59.070190.002143

Bhargava, A., Osusky, M., Hancock, R. E., Forward, B. S., Kay, W. W., and Misra, S. (2007). Antiviral indolicidin variant peptides: evaluation for broad-spectrum 
disease resistance in transgenic Nicotiana tabacum. Plant Sci. 172, 515-523. doi: 10.1016/j.plantsci.2006.10.016

Boman, H. G. (1995). Peptide antibiotics and their role in innate immunity. Annu. Rev. Immunol. 13, 61-92. doi: 10.1146/annurev.iy.13.040195.000425

Brocal, I., Falco, A., Mas, V., Rocha, A., Perez, L., Coll, J. M., et al. (2006). Stable expression of bioactive recombinant pleurocidin in a fish cell line. Appl. Microbiol. Biotechnol. 72, 1217-1228. doi: 10.1007/s00253-006-0393-7

Burrowes, O. J., Diamond, G., and Lee, T. C. (2005). Recombinant expression of pleurocidin cDNA using the Pichia pastoris expression system. J. Biomed. Biotechnol. 2005, 374-384. doi: 10.1155/JBB.2005.374

Cao, P., Yu, J., Lu, W., Cai, X., Wang, Z., Gu, Z., et al. (2010). Expression and purification of an antitumor-analgesic peptide from the venom of Mesobuthus martensii Karsch by small ubiquitin-related modifier fusion in Escherichia coli. Biotechnol. Prog. 26, 1240-1244. doi: 10.1002/btpr.433

Carriel-Gomes, M. C., Kratz, J. M., Barracco, M. A., Bachere, E., Barardi, C. R., and Simoes, C. M. (2007). In vitro antiviral activity of antimicrobial peptides against herpes simplex virus 1, adenovirus, and rotavirus. Mem. Inst. Oswaldo Cruz 102, 469-472. doi: 10.1590/S0074-02762007005000028

Carroll, A., Bowden, B., Coll, J., Hockless, D., Skelton, B., and White, A. (1994). Studies of australian ascidians. IV., mollamide, a cytotoxic cyclic heptapeptide from the compound ascidian didemnum molle. Aust. J. Chem. 47, 61-69. doi: 10.1071/CH9940061

Carroll, A. R., Feng, Y., Bowden, B. F., and Coll, J. C. (1996). Studies of australian ascidians. 5. virenamides A-C, new cytotoxic linear peptides from the colonial didemnid ascidian diplosoma virens. J. Org. Chem. 61, 4059-4061. doi: 10.1021/jo951379o

Chan, S. C., Hui, L., and Chen, H. M. (1998a). Enhancement of the cytolytic effect of anti-bacterial cecropin by the microvilli of cancer cells. Anticancer Res. 18, 4467-4474.

Chan, S. C., Yau, W. L., Wang, W., Smith, D. K., Sheu, F. S., and Chen, H. M. (1998b). Microscopic observations of the different morphological changes caused by anti-bacterial peptides on Klebsiella pneumoniae and HL-60 leukemia cells. J. Pept. Sci. 4, 413-425. doi: 10.1002/(SICI)10991387(199811)4:7<413::AID-PSC160>3.0.CO;2-W

Chaudhary, J., and Munshi, M. (1995). Scanning electron microscopic analysis of breast aspirates. Cytopathology 6, 162-167. doi: 10.1111/j.13652303.1995.tb00469.x

Chen, H. M., Wang, W., Smith, D., and Chan, S. C. (1997). Effects of the anti-bacterial peptide cecropin B and its analogs, cecropins B-1 and B-2, on liposomes, bacteria, and cancer cells. Biochim. Biophys. Acta 1336, 171-179. doi: 10.1016/S0304-4165(97)00024-X

Chen, J., Xu, X. M., Underhill, C. B., Yang, S., Wang, L., Chen, Y., et al. (2005). Tachyplesin activates the classic complement pathway to kill tumor cells. Cancer Res. 65, 4614-4622. doi: 10.1158/0008-5472.CAN-04-2253

Chen, Y. L., Li, J. H., Yu, C. Y., Lin, C. J., Chiu, P. H., Chen, P. W., et al. (2012). Novel cationic antimicrobial peptide GW-H1 induced caspase-dependent apoptosis of hepatocellular carcinoma cell lines. Peptides 36, 257-265. doi: 10.1016/j.peptides.2012.05.011

Chen, Z. C., White, R. F., Antoniw, J. F., and Lin, Q. (1991). Effect of pokeweed antiviral protein (PAP) on the infection of plant viruses. Plant Pathol. 40, 612-620. doi: 10.1111/j.1365-3059.1991.tb02426.x

Cheng, L., Wang, C., Liu, H., Wang, F., Zheng, L., Zhao, J., et al. (2012). A novel polypeptide extracted from Ciona savignyi induces apoptosis through a mitochondrial-mediated pathway in human colorectal carcinoma cells. Clin. Colorectal Cancer 11, 207-214. doi: 10.1016/j.clcc.2012.01.002

Chernysh, S., Irina, K., and Irina, A. (2012). Anti-tumor activity of immunomodulatory peptide alloferon-1 in mouse tumor transplantation model. Int. Immunopharmacol. 12, 312-314. doi: 10.1016/j.intimp.2011.10.016

Chernysh, S., Kim, S. I., Bekker, G., Pleskach, V. A., Filatova, N. A., Anikin, V. B., et al. (2002). Antiviral and antitumor peptides from insects. Proc. Natl. Acad. Sci. U.S.A. 99, 12628-12632. doi: 10.1073/pnas.192301899

Chia, T. J., Wu, Y. C., Chen, J. Y., and Chi, S. C. (2010). Antimicrobial peptides (AMP) with antiviral activity against fish nodavirus. Fish Shellfish Immunol. 28, 434-439. doi: 10.1016/j.fsi.2009.11.020

Chiou, P. P., Lin, C. M., Perez, L., and Chen, T. T. (2002). Effect of cecropin B and a synthetic analogue on propagation of fish viruses in vitro. Mar. Biotechnol. 4, 294-302. doi: 10.1007/s10126-002-0021-1

Chuang, C. M., Monie, A., Wu, A., Mao, C. P., and Hung, C. F. (2009). Treatment with LL-37 peptide enhances antitumor effects induced by CpG oligodeoxynucleotides against ovarian cancer. Hum. Gene Ther. 20, 303-313. doi: 10.1089/hum.2008.124

Cole, A. M., Hong, T., Boo, L. M., Nguyen, T., Zhao, C., Bristol, G., et al. (2002). Retrocyclin: a primate peptide that protects cells from infection by $\mathrm{T}$ - and M-tropic strains of HIV-1. Proc. Natl. Acad. Sci. U.S.A. 99, 1813-1818. doi: 10.1073/pnas.052706399

Craik, D. J., Fairlie, D. P., Liras, S., and Price, D. (2013). The future of peptide-based drugs. Chem. Biol. Drug Des. 81, 136-147. doi: 10.1111/cbdd.12055

Craik, D. J., and Malik, U. (2013). Cyclotide biosynthesis. Curr. Opin. Chem. Biol. 17, 546-554. doi: 10.1016/j.cbpa.2013.05.033

Cruciani, R. A., Barker, J. L., Zasloff, M., Chen, H. C., and Colamonici, O. (1991). Antibiotic magainins exert cytolytic activity against transformed cell lines through channel formation. Proc. Natl. Acad. Sci. U.S.A. 88, 3792-3796. doi: $10.1073 /$ pnas.88.9.3792

Cruz-Chamorro, L., Puertollano, M. A., Puertollano, E., De Cienfuegos, G. A., and De Pablo, M. A. (2006). In vitro biological activities of magainin alone or in combination with nisin. Peptides 27, 1201-1209. doi: 10.1016/j.peptides.2005.11.008

Daher, K. A., Selsted, M. E., and Lehrer, R. I. (1986). Direct inactivation of viruses by human granulocyte defensins. J. Virol. 60, 1068-1074.

Daly, N. L., Koltay, A., Gustafson, K. R., Boyd, M. R., Casas-Finet, J. R., and Craik, D. J. (1999). Solution structure by NMR of circulin A: a macrocyclic knotted peptide having anti-HIV activity. J. Mol. Biol. 285, 333-345. doi: 10.1006/jmbi.1998.2276

De Clerq, E. (2008). Antivirals: current state of the art. Future Virol. 3, 393-405. doi: 10.2217/17460794.3.4.393

Dobrzynska, I., Szachowicz-Petelska, B., Sulkowski, S., and Figaszewski, Z. (2005). Changes in electric charge and phospholipids composition in human colorectal cancer cells. Mol. Cell. Biochem. 276, 113-119. doi: 10.1007/s11010-005-3557-3

Doyle, J., Brinkworth, C. S., Wegener, K. L., Carver, J. A., Llewellyn, L. E., Olver, I. N., et al. (2003). nNOS inhibition, antimicrobial and anticancer activity of the amphibian skin peptide, citropin 1.1 and synthetic modifications. The solution structure of a modified citropin 1.1. Eur. J. Biochem. 270, 1141-1153. doi: 10.1046/j.1432-1033.2003.03462.x

Ebada, S. S., Wray, V., De Voogd, N. J., Deng, Z., Lin, W., and Proksch, P. (2009). Two new jaspamide derivatives from the marine sponge Jaspis splendens. Mar Drugs 7, 434-444. doi: 10.3390/md7030435

Edler, M. C., Fernandez, A. M., Lassota, P., Ireland, C. M., and Barrows, L. R. (2002). Inhibition of tubulin polymerization by vitilevuamide, a bicyclic marine peptide, at a site distinct from colchicine, the vinca alkaloids, and dolastatin 10 Biochem. Pharmacol. 63, 707-715. doi: 10.1016/S0006-2952(01)00898-X

Edwards, D. J., Marquez, B. L., Nogle, L. M., McPhail, K., Goeger, D. E., Roberts, M. A., et al. (2004). Structure and biosynthesis of the jamaicamides, new mixed polyketide-peptide neurotoxins from the marine cyanobacterium Lyngbya majuscula. Chem. Biol. 11, 817-833. doi: 10.1016/j.chembiol. 2004.03.030

Eliassen, L. T., Berge, G., Leknessund, A., Wikman, M., Lindin, I., Lokke, C., et al. (2006). The antimicrobial peptide, lactoferricin B, is cytotoxic to neuroblastoma cells in vitro and inhibits xenograft growth in vivo. Int. J. Cancer 119, 493-500. doi: 10.1002/ijc. 21886

Escudero, E., Aristoy, M. C., Nishimura, H., Arihara, K., and Toldra, F. (2012). Antihypertensive effect and antioxidant activity of peptide fractions extracted from Spanish dry-cured ham. Meat Sci. 91, 306-311. doi: 10.1016/j.meatsci.2012.02.008

Faivre, S., Chieze, S., Delbaldo, C., Ady-Vago, N., Guzman, C., Lopez-Lazaro, L., et al. (2005). Phase I and pharmacokinetic study of aplidine, a new marine cyclodepsipeptide in patients with advanced malignancies. J. Clin. Oncol. 23, 7871-7880. doi: 10.1200/JCO.2005.09.357

Falco, A., Mas, V., Tafalla, C., Perez, L., Coll, J. M., and Estepa, A. (2007). Dual antiviral activity of human alpha-defensin-1 against viral haemorrhagic septicaemia rhabdovirus (VHSV): Inactivation of virus particles and induction of a type I interferon-related response. Antivir. Res. 76, 111-123. doi: 10.1016/j.antiviral.2007.06.006

Falco, A., Ortega-Villaizan, M., Chico, V., Brocal, I., Perez, L., Coll, J. M., et al. (2009). Antimicrobial peptides as model molecules for the development of novel antiviral agents in aquaculture. Mini Rev. Med. Chem. 9, 1159-1164. doi: 10.2174/138955709789055171

Feng, X., Liu, C., Guo, J., Song, X., Li, J., Xu, W., et al. (2011). Recombinant expression, purification, and antimicrobial activity of a novel hybrid 
antimicrobial peptide LFT33. Appl. Microbiol. Biotechnol. 95, 1191-1198. doi: 10.1007/s00253-011-3816-Z

Findlay, E. G., Currie, S. M., and Davidson, D. J. (2013). Cationic host defence peptides: potential as antiviral therapeutics. BioDrugs 27, 479-493. doi: 10.1007/ s40259-013-0039-0

Fisher, P. J., Prendergast, F. G., Ehrhardt, M. R., Urbauer, J. L., Wand, A. J., Sedarous, S. S., et al. (1994). Calmodulin interacts with amphiphilic peptides composed of all D-amino acids. Nature 368, 651-653. doi: 10.1038/368651a0

Fox, J. L. (2013). Antimicrobial peptides stage a comeback. Nat. Biotechnol. 31, 379-382. doi: $10.1038 /$ nbt.2572

Franco, O. L. (2011). Peptide promiscuity: an evolutionary concept for plant defense. FEBS Lett. 585, 995-1000. doi: 10.1016/j.febslet.2011.03.008

Franco, O. L., Murad, A. M., Leite, J. R., Mendes, P. A., Prates, M. V., and Bloch, C. Jr. (2006). Identification of a cowpea gamma-thionin with bactericidal activity. FEBS J. 273, 3489-3497. doi: 10.1111/j.1742-4658.2006.05349.x

Freitas, V. M., Rangel, M., Bisson, L. F., Jaeger, R. G., and Machado-Santelli, G. M. (2008). The geodiamolide $\mathrm{H}$, derived from Brazilian sponge Geodia corticostylifera, regulates actin cytoskeleton, migration and invasion of breast cancer cells cultured in three-dimensional environment. J. Cell. Physiol. 216, 583-594. doi: $10.1002 /$ jcp. 21432

Ganz, T., Selsted, M. E., Szklarek, D., Harwig, S. S., Daher, K., Bainton, D. F., et al. (1985). Defensins. Natural peptide antibiotics of human neutrophils. J. Clin. Invest. 76, 1427-1435. doi: 10.1172/JCI112120

Ghavami, S., Asoodeh, A., Klonisch, T., Halayko, A. J., Kadkhoda, K., Kroczak, T. J., et al. (2008). Brevinin-2R(1) semi-selectively kills cancer cells by a distinct mechanism, which involves the lysosomal-mitochondrial death pathway. J. Cell. Mol. Med. 12, 1005-1022. doi: 10.1111/j.1582-4934.2008.00129.x

Ghosh, A. K., Dawson, Z. L., Moon, D. K., Bai, R., and Hamel, E. (2010). Synthesis and biological evaluation of new jasplakinolide (jaspamide) analogs. Bioorg. Med. Chem. Lett. 20, 5104-5107. doi: 10.1016/j.bmcl.2010.07.023

Gifford, J. L., Hunter, H. N., and Vogel, H. J. (2005). Lactoferricin: a lactoferrinderived peptide with antimicrobial, antiviral, antitumor and immunological properties. Cell. Mol. Life Sci. 62, 2588-2598. doi: 10.1007/s00018-005-5373-z

Gordon, Y. J., Romanowski, E. G., Shanks, R. M., Yates, K. A., Hinsley, H., and Pereira, H. A. (2009). CAP37-derived antimicrobial peptides have in vitro antiviral activity against adenovirus and herpes simplex virus type 1. Curr. Eye Res. 34, 241-249. doi: 10.1080/02713680802714066

Gracia, C., Isidro-Llobet, A., Cruz, L. J., Acosta, G. A., Alvarez, M., Cuevas, C., et al. (2006). Convergent approaches for the synthesis of the antitumoral peptide, Kahalalide, F. Study of orthogonal protecting groups. J. Org. Chem. 71, 7196-7204. doi: 10.1021/jo060976f

Gravitt, K. R., Ward, N. E., and O'brian, C. A. (1994). Inhibition of protein kinase $\mathrm{C}$ by melittin: antagonism of binding interactions between melittin and the catalytic domain by active-site binding of MgATP. Biochem. Pharmacol. 47, 425-427. doi: 10.1016/0006-2952(94)90037-X

Gropp, R., Frye, M., Wagner, T. O., and Bargon, J. (1999). Epithelial defensins impair adenoviral infection: implication for adenovirus-mediated gene therapy. Hum. Gene Ther. 10, 957-964. doi: 10.1089/10430349950018355

Gu, Y., Liu, S. L., Ju, W. Z., Li, C. Y., and Cao, P. (2013). Analgesic-antitumor peptide induces apoptosis and inhibits the proliferation of SW480 human colon cancer cells. Oncol Lett. 5, 483-488.

Guevara, M. G., Muñoz, F. F., Fernández, M. B., Mendieta, J. R., and Daleo, G. R. (2011). Isolation of a New Antimicrobial/Antitumor Plant Peptide: Biotechnology Prospects For Its Use in Cancer And Infectious Diseases Therapies. Spain: Formatex.

Hallock, K. J., Lee, D. K., Omnaas, J., Mosberg, H. I., and Ramamoorthy, A. (2002). Membrane composition determines pardaxin's mechanism of lipid bilayer disruption. Biophys. J. 83, 1004-10013. doi: 10.1016/S0006-3495(02) 75226-0

Hamann, M. T., Otto, C. S., Scheuer, P. J., and Dunbar, D. C. (1996). Kahalalides: bioactive peptides from a marine mollusk Elysia rufescens and its algal diet bryopsis sp.(1). J. Org. Chem. 61, 6594-6600. doi: 10.1002/chin.199705228

Hambley, T. W., Hawkins, C. J., Lavin, M. F., Van Den Brenk, A., and Watters, D. J. (1992). Cycloxazoline: a cytotoxic cyclic hexapeptide from the ascidian lissoclinum bistratum. Tetrahedron 48, 341-348. doi: 10.1016/S00404020(01)88146-1

Hancock, R. E. (2001). Cationic peptides: effectors in innate immunity and novel antimicrobials. Lancet Infect. Dis. 1, 156-164. doi: 10.1016/S14733099(01)00092-5
Hancock, R. E., and Chapple, D. S. (1999). Peptide antibiotics. Antimicrob. Agents Chemother. 43, 1317-1323.

Hancock, R. E. W., and Sahl, H.-G. (2006). Antimicrobial and host-defense peptides as new anti-infective therapeutic strategies. Nat. Biotechnol. 24, 1551-1557. doi: $10.1038 /$ nbt1267

Harmsen, M. C., Swart, P. J., De Bethune, M. P., Pauwels, R., De Clercq, E., The, T. H., et al. (1995). Antiviral effects of plasma and milk proteins: lactoferrin shows potent activity against both human immunodeficiency virus and human cytomegalovirus replication in vitro. J. Infect. Dis. 172, 380-388. doi: 10.1093/infdis/172.2.380

Held-Kuznetsov, V., Rotem, S., Assaraf, Y. G., and Mor, A. (2009). Host-defense peptide mimicry for novel antitumor agents. FASEB J. 23, 4299-4307. doi: 10.1096/fj.09-136358

Henzler-Wildman, K. A., Martinez, G. V., Brown, M. F., and Ramamoorthy, A. (2004). Perturbation of the hydrophobic core of lipid bilayers by the human antimicrobial peptide LL-37. Biochemistry 43, 8459-8469. doi: 10.1021/bi036284s

Henzler Wildman, K. A., Lee, D. K., and Ramamoorthy, A. (2003). Mechanism of lipid bilayer disruption by the human antimicrobial peptide, LL-37. Biochemistry 42, 6545-6558. doi: 10.1021/bi0273563

Hitotsuyanagi, Y., Ishikawa, H., Hasuda, T., and Takeya, K. (2004). Isolation, structural elucidation, and synthesis of RA-XVII, a novel bicyclic hexapeptide from Rubia cordifolia, and the effect of side chain at residue 1 upon the conformation and cytotoxic activity. Tetrahedron Lett. 45, 935-938. doi: 10.1016/j.tetlet.2003.11.112

Hook, L. M., Lubinski, J. M., Jiang, M., Pangburn, M. K., and Friedman, H. M. (2006). Herpes simplex virus type 1 and 2 glycoprotein $C$ prevents complement-mediated neutralization induced by natural immunoglobulin $\mathrm{M}$ antibody. J. Virol. 80, 4038-4046. doi: 10.1128/JVI.80.8.4038-4046.2006

Horgen, F. D., Kazmierski, E. B., Westenburg, H. E., Yoshida, W. Y., and Scheuer, P. J. (2002). Malevamide D: isolation and structure determination of an isodolastatin $\mathrm{H}$ analogue from the marine cyanobacterium Symploca hydnoides. J. Nat. Prod. 65, 487-491. doi: 10.1021/np010560r

Hoskin, D. W., and Ramamoorthy, A. (2008). Studies on anticancer activities of antimicrobial peptides. Biochim. Biophys. Acta 1778, 357-375. doi: 10.1016/j.bbamem.2007.11.008

Hou, L., Zhao, X., Wang, P., Ning, Q., Meng, M., and Liu, C. (2013). Antitumor activity of antimicrobial peptides containing CisoDGRC in CD13 negative breast cancer cells. PLoS ONE 8:e53491. doi: 10.1371/journal.pone.0053491

Hsieh, C. C., Hernandez-Ledesma, B., and De Lumen, B. O. (2010). Soybean peptide lunasin suppresses in vitro and in vivo 7, 12-dimethylbenz[a] anthraceneinduced tumorigenesis. J. Food Sci. 75, H311-H316. doi: 10.1111/j.17503841.2010.01861.x

Hsieh, P. W., Chang, F. R., Wu, C. C., Li, C. M., Wu, K. Y., Chen, S. L., et al. (2005). Longicalycinin, A, a new cytotoxic cyclic peptide from Dianthus superbus var. longicalycinus (MAXIM.) WILL. Chem. Pharm. Bull. 53, 336-338. doi: $10.1248 /$ cpb. 53.336

Hsieh, P. W., Chang, F. R., Wu, C. C., Wu, K. Y., Li, C. M., Chen, S. L., et al. (2004). New cytotoxic cyclic peptides and dianthramide from Dianthus superbus. J. Nat. Prod. 67, 1522-1527. doi: 10.1021/np040036v

Hsu, C. H., Chen, C., Jou, M. L., Lee, A. Y., Lin, Y. C., Yu, Y. P., et al. (2005). Structural and DNA-binding studies on the bovine antimicrobial peptide, indolicidin: evidence for multiple conformations involved in binding to membranes and DNA. Nucleic Acids Res. 33, 4053-4064. doi: 10.1093/nar/gki725

Hu, J., Chen, C., Zhang, S., Zhao, X., Xu, H., and Lu, J. R. (2011). Designed antimicrobial and antitumor peptides with high selectivity. Biomacromolecules 12, 3839-3843. doi: 10.1021/bm201098j

Huang, L., Ching, C. B., Jiang, R., and Leong, S. S. (2008). Production of bioactive human beta-defensin 5 and 6 in Escherichia coli by soluble fusion expression. Protein Expr. Purif. 61, 168-174. doi: 10.1016/j.pep.2008.05.016

Huang, L., Leong, S. S., and Jiang, R. (2009). Soluble fusion expression and characterization of bioactive human beta-defensin 26 and 27. Appl. Microbiol. Biotechnol. 84, 301-308. doi: 10.1007/s00253-009-1982-z

Huang, T. C., Lee, J. F., and Chen, J. Y. (2011). Pardaxin, an antimicrobial peptide, triggers caspase-dependent and ROS-mediated apoptosis in HT-1080 cells. Mar Drugs 9, 1995-2009. doi: 10.3390/md9101995

Hull, R. (2002). Mathew's Plant Virology. San Diego, CA: Academic Press.

Ikeda, M., Sugiyama, K., Tanaka, T., Tanaka, K., Sekihara, H., Shimotohno, K., et al. (1998). Lactoferrin markedly inhibits hepatitis C virus infection in 
cultured human hepatocytes. Biochem. Biophys. Res. Commun. 245, 549-553. doi: 10.1006/bbrc. 1998.8481

Itazaki, H., Nagashima, K., Sugita, K., Yoshida, H., Kawamura, Y., Yasuda, Y., et al. (1990). Isolation and structural elucidation of new cyclotetrapeptides, trapoxins $\mathrm{A}$ and B, having detransformation activities as antitumor agents. J. Antibiot. 43, 1524-1532. doi: 10.7164/antibiotics.43.1524

Jacob, L., and Zasloff, M. (1994). Potential therapeutic applications of magainins and other antimicrobial agents of animal origin. Ciba Found. Symp. 186, 197-216; discussion 216-123.

Jan, P. S., Huang, H. Y., and Chen, H. M. (2010). Expression of a synthesized gene encoding cationic peptide cecropin B in transgenic tomato plants protects against bacterial diseases. Appl. Environ. Microbiol. 76, 769-775. doi: 10.1128/AEM.00698-09

Jenssen, H., Andersen, J. H., Uhlin-Hansen, L., Gutteberg, T. J., and Rekdal, O. (2004). Anti-HSV activity of lactoferricin analogues is only partly related to their affinity for heparan sulfate. Antivir. Res. 61, 101-109. doi: 10.1016/j.antiviral.2003.09.001

Jenssen, H., Hamill, P., and Hancock, R. E. (2006). Peptide antimicrobial agents. Clin. Microbiol. Rev. 19, 491-511. doi: 10.1128/CMR.00056-05

Jin, F., Xu, X., Zhang, W., and Gu, D. (2006). Expression and characterization of a housefly cecropin gene in the methylotrophic yeast, Pichia pastoris. Protein Expr. Purif. 49, 39-46. doi: 10.1016/j.pep.2006.03.008

Kalemkerian, G. P., Ou, X., Adil, M. R., Rosati, R., Khoulani, M. M., Madan, S. K., et al. (1999). Activity of dolastatin 10 against small-cell lung cancer in vitro and in vivo: induction of apoptosis and bcl-2 modification. Cancer Chemother. Pharmacol. 43, 507-515. doi: 10.1007/s002800050931

Kaur, I., Gupta, R. C., and Puri, M. (2011). Ribosome inactivating proteins from plants inhibiting viruses. Virol. Sin. 26, 357-365. doi: 10.1007/s12250-0113223-8

Kim, H. K., Chun, D. S., Kim, J. S., Yun, C. H., Lee, J. H., Hong, S. K., et al. (2006). Expression of the cationic antimicrobial peptide lactoferricin fused with the anionic peptide in Escherichia coli. Appl. Microbiol. Biotechnol. 72, 330-338. doi: 10.1007/s00253-005-0266-5

Kinchington, D., Kangro, H., and Jeffries, K. J. (1995). Design and Testing of Antiviral Compounds. New York, NY: Oxford University Press.

Kobayashi, M., Kurosu, M., Ohyabu, N., Wang, W., Fujii, S., and Kitagawa, I. (1994). The absolute stereostructure of Arenastatin, A, a potent cytotoxic depsipeptide from the Okinawan marine sponge Dysidea arenaria. Chem. Pharm. Bull. 42, 2196-2198. doi: 10.1248/cpb.42.2196

Koszalka, P., Kamysz, E., Wejda, M., Kamysz, W., and Bigda, J. (2011). Antitumor activity of antimicrobial peptides against U937 histiocytic cell line. Acta Biochim. Pol. 58, 111-117.

Lax, R. T. (2010). The future of peptide development in the pharmaceutical industry. PharManufacturing 10-15.

Lee, H. S., Park, C. B., Kim, J. M., Jang, S. A., Park, I. Y., Kim, M. S., et al. (2008). Mechanism of anticancer activity of buforin IIb, a histone H2A-derived peptide. Cancer Lett. 271, 47-55. doi: 10.1016/j.canlet.2008. 05.041

Lee, S. B., Li, B., Jin, S., and Daniell, H. (2011). Expression and characterization of antimicrobial peptides Retrocyclin-101 and Protegrin-1 in chloroplasts to control viral and bacterial infections. Plant Biotechnol. J. 9, 100-115. doi: 10.1111/j.1467-7652.2010.00538.x

Lehmann, J., Retz, M., Sidhu, S. S., Suttmann, H., Sell, M., Paulsen, F., et al. (2006). Antitumor activity of the antimicrobial peptide magainin II against bladder cancer cell lines. Eur. Urol. 50, 141-147. doi: 10.1016/j.eururo.2005.12.043

Leuschner, C., and Hansel, W. (2004). Membrane disrupting lytic peptides for cancer treatments. Curr. Pharm. Des. 10, 2299-2310. doi: $10.2174 / 1381612043383971$

Li, H., Kolluri, S. K., Gu, J., Dawson, M. I., Cao, X., Hobbs, P. D., et al. (2000). Cytochrome c release and apoptosis induced by mitochondrial targeting of nuclear orphan receptor TR3. Science 289, 1159-1164. doi: 10.1126/science.289.5482.1159

Li, J. F., Zhang, J., Zhang, Z., Ma, H. W., Zhang, J. X., and Zhang, S. Q. (2010). Production of bioactive human beta-defensin-4 in Escherichia coli using SUMO fusion partner. Protein J. 29, 314-319. doi: 10.1007/s10930-0109254-4

Li, W. L., Yi, Y. H., Wu, H. M., Xu, Q. Z., Tang, H. F., Zhou, D. Z., et al. (2003). Isolation and structure of the cytotoxic cycloheptapeptide phakellistatin 13. J. Nat. Prod. 66, 146-148. doi: 10.1021/np020223y
Liang, Y., Wang, J. X., Zhao, X. F., Du, X. J., and Xue, J. F. (2006). Molecular cloning and characterization of cecropin from the housefly (Musca domestica), and its expression in Escherichia coli. Dev. Comp. Immunol. 30, 249-257. doi: 10.1016/j.dci.2005.04.005

Liu, S., Yang, H., Wan, L., Cheng, J., and Lu, X. (2013). Penetratin-mediated delivery enhances the antitumor activity of the cationic antimicrobial peptide magainin, I. I. Cancer Biother. Radiopharm. 28, 289-297. doi: 10.1089/cbr.2012. 1328

Luo, H., Chen, S., Ren, F., Guo, H., Lin, S., and Xu, W. (2007). In vitro reconstitution of antimicrobial pathogen activity by expressed recombinant bovine lactoferrin N-terminal peptide in Escherichia coli. J. Dairy Res. 74, 233-238. doi: 10.1017/S0022029907002531

Ma, D., Zou, B., Cai, G., Hu, X., and Liu, J. O. (2006). Total synthesis of the cyclodepsipeptide apratoxin A and its analogues and assessment of their biological activities. Chemistry 12, 7615-7626. doi: 10.1002/chem.200600599

Mader, J. S., and Hoskin, D. W. (2006). Cationic antimicrobial peptides as novel cytotoxic agents for cancer treatment. Expert Opin. Investig. Drugs 15, 933-946. doi: $10.1517 / 13543784.15 .8 .933$

Mader, J. S., Salsman, J., Conrad, D. M., and Hoskin, D. W. (2005). Bovine lactoferricin selectively induces apoptosis in human leukemia and carcinoma cell lines. Mol. Cancer Ther. 4, 612-624. doi: 10.1158/1535-7163.MCT-04-0077

Mader, J. S., Smyth, D., Marshall, J., and Hoskin, D. W. (2006). Bovine lactoferricin inhibits basic fibroblast growth factor- and vascular endothelial growth factor165-induced angiogenesis by competing for heparin-like binding sites on endothelial cells. Am. J. Pathol. 169, 1753-1766. doi: 10.2353/ajpath.2006.051229

Mai, J. C., Mi, Z., Kim, S. H., Ng, B., and Robbins, P. D. (2001). A proapoptotic peptide for the treatment of solid tumors. Cancer Res. 61, 7709-7712.

Malaker, A., and Ahmad, S. A. I. (2013). Therapeutic potency of anticancer peptides derived from marine organisms. Int. J. Eng. Appl. Sci. 2, 82-94.

Mandal, S. M., Migliolo, L., Das, S., Mandal, M., Franco, O. L., and Hazra, T. K. (2012). Identification and characterization of a bactericidal and proapoptotic peptide from Cycas revoluta seeds with DNA binding properties. J. Cell. Biochem. 113, 184-193. doi: 10.1002/jcb.23343

Mandal, S. M., Porto, W. F., Dey, P., Maiti, M. K., Ghosh, A. K., and Franco, O. L. (2013). The attack of the phytopathogens and the trumpet solo: identification of a novel plant antifungal peptide with distinct fold and disulfide bond pattern. Biochimie. 95, 1939-1948. doi: 10.1016/j.biochi.2013.06.027

Marcos, J. F., Beachy, R. N., Houghten, R. A., Blondelle, S. E., and PerezPaya, E. (1995). Inhibition of a plant virus infection by analogs of melittin. Proc. Natl. Acad. Sci. U.S.A. 92, 12466-12469. doi: 10.1073/ pnas. 92.26 .12466

Martin-Algarra, S., Espinosa, E., Rubio, J., Lopez Lopez, J. J., Manzano, J. L., Carrion, L. A., et al. (2009). Phase II study of weekly Kahalalide F in patients with advanced malignant melanoma. Eur. J. Cancer 45, 732-735. doi: 10.1016/j.ejca.2008.12.005

Matsuzaki, K., Murase, O., Fujii, N., and Miyajima, K. (1996). An antimicrobial peptide, magainin 2, induced rapid flip-flop of phospholipids coupled with pore formation and peptide translocation. Biochemistry 35, 11361-11368. doi: 10.1021/bi960016v

McDaniel, J. R., Callahan, D. J., and Chilkoti, A. (2010). Drug delivery to solid tumors by elastin-like polypeptides. Adv. Drug Deliv. Rev. 62, 1456-1467. doi: 10.1016/j.addr.2010.05.004

McKeown, S. T., Lundy, F. T., Nelson, J., Lockhart, D., Irwin, C. R., Cowan, C. G., et al. (2006). The cytotoxic effects of human neutrophil peptide-1 (HNP1) and lactoferrin on oral squamous cell carcinoma (OSCC) in vitro. Oral Oncol. 42, 685-690. doi: 10.1016/j.oraloncology.2005.11.005

Medina, R. A., Goeger, D. E., Hills, P., Mooberry, S. L., Huang, N., Romero, L. I., et al. (2008). Coibamide, A, a potent antiproliferative cyclic depsipeptide from the Panamanian marine cyanobacterium Leptolyngbya sp. J. Am. Chem. Soc. 130, 6324-6325. doi: 10.1021/ja801383f

Mendieta, J. R., Fimognari, C., Daleo, G. R., Hrelia, P., and Guevara, M. G. (2010). Cytotoxic effect of potato aspartic proteases (StAPs) on Jurkat T cells. Fitoterapia 81, 329-335. doi: 10.1016/j.fitote.2009.10.004

Mendoza, F. J., Espino, P. S., Cann, K. L., Bristow, N., McCrea, K., and Los, M. (2005). Anti-tumor chemotherapy utilizing peptide-based approachesapoptotic pathways, kinases, and proteasome as targets. Arch. Immunol. Ther. Exp. 53, 47-60. 
Migliolo, L., Silva, O. N., Silva, P. A., Costa, M. P., Costa, C. R., Nolasco, D. O., et al. (2012). Structural and functional characterization of a multifunctional alaninerich peptide analogue from Pleuronectes americanus. PLOS ONE 7:e47047. doi: 10.1371/journal.pone.0047047

Mistry, N., Drobni, P., Naslund, J., Sunkari, V. G., Jenssen, H., and Evander, M. (2007). The anti-papillomavirus activity of human and bovine lactoferricin. Antivir. Res. 75, 258-265. doi: 10.1016/j.antiviral.2007.03.012

Mooberry, S. L., Leal, R. M., Tinley, T. L., Luesch, H., Moore, R. E., and Corbett, T. H. (2003). The molecular pharmacology of symplostatin 1: a new antimitotic dolastatin 10 analog. Int. J. Cancer 104, 512-521. doi: 10.1002/ ijc. 10982

Moon, J. Y., Henzler-Wildman, K. A., and Ramamoorthy, A. (2006). Expression and purification of a recombinant LL-37 from Escherichia coli. Biochim. Biophys. Acta 1758, 1351-1358. doi: 10.1016/j.bbamem.2006.02.003

Morimoto, M., Mori, H., Otake, T., Ueba, N., Kunita, N., Niwa, M., et al. (1991). Inhibitory effect of tachyplesin I on the proliferation of human immunodeficiency virus in vitro. Chemotherapy 37, 206-211. doi: 10.1159/000238855

Morin, K. M., Arcidiacono, S., Beckwitt, R., and Mello, C. M. (2006). Recombinant expression of indolicidin concatamers in Escherichia coli. Appl. Microbiol. Biotechnol. 70, 698-704. doi: 10.1007/s00253-005-0132-5

Munk, C., Wei, G., Yang, O. O., Waring, A. J., Wang, W., Hong, T., et al. (2003). The theta-defensin, retrocyclin, inhibits HIV-1 entry. AIDS Res. Hum. Retroviruses 19, 875-881. doi: 10.1089/088922203322493049

Murakami, T., Niwa, M., Tokunaga, F., Miyata, T., and Iwanaga, S. (1991). Direct virus inactivation of tachyplesin I and its isopeptides from horseshoe crab hemocytes. Chemotherapy 37, 327-334. doi: 10.1159/000238875

Nakashima, H., Masuda, M., Murakami, T., Koyanagi, Y., Matsumoto, A., Fujii, N., et al. (1992). Anti-human immunodeficiency virus activity of a novel synthetic peptide, T22 ([Tyr-5 12, Lys-7]polyphemusin II): a possible inhibitor of virus-cell fusion. Antimicrob. Agents Chemother. 36, 1249-1255. doi: 10.1128/AAC.36.6.1249

Nakashima, H., Yamamoto, N., Masuda, M., and Fujii, N. (1993). Defensins inhibit HIV replication in vitro. AIDS 7, 1129. doi: 10.1097/00002030-19930800000019

Nguyen, L. T., Haney, E. F., and Vogel, H. J. (2011). The expanding scope of antimicrobial peptide structures and their modes of action. Trends Biotechnol. 29, 464-472. doi: 10.1016/j.tibtech.2011.05.001

Oka, M., Ohkuma, H., Kamei, H., Konishi, M., Oki, T., and Kawaguchi, H. (1988). Glidobactins, D, E, F, G and H; minor components of the antitumor antibiotic glidobactin. J. Antibiot. 41, 1906-1909. doi: 10.7164/antibiotics.41.1906

Okubo, B. M., Silva, O. N., Migliolo, L., Gomes, D. G., Porto, W. F., Batista, C. L., et al. (2012). Evaluation of an antimicrobial L-amino acid oxidase and peptide derivatives from Bothropoides mattogrosensis pitviper venom. PLoS ONE 7:e33639. doi: 10.1371/journal.pone.0033639

Onwulata, C. I. (2012). Encapsulation of new active ingredients. Annu. Rev. Food Sci. Technol. 3, 183-202. doi: 10.1146/annurev-food-022811-101140

Parachin, N. S., Mulder, K. C., Viana, A. A. B., Dias, S. C., and Franco, O. L. (2012). Expression systems for heterologous production of antimicrobial peptides. Peptides 38, 446-456. doi: 10.1016/j.peptides.2012.09.020

Papo, N., and Shai, Y. (2005). Host defense peptides as new weapons in cancer treatment. Cell. Mol. Life Sci. 62, 784-790. doi: 10.1007/s00018-005-4560-2

Paredes-Gamero, E. J., Martins, M. N., Cappabianco, F. A., Ide, J. S., and Miranda, A. (2012). Characterization of dual effects induced by antimicrobial peptides: regulated cell death or membrane disruption. Biochim. Biophys. Acta 1820, 1062-1072. doi: 10.1016/j.bbagen.2012.02.015

Park, C. B., Kim, H. S., and Kim, S. C. (1998). Mechanism of action of the antimicrobial peptide buforin II: buforin II kills microorganisms by penetrating the cell membrane and inhibiting cellular functions. Biochem. Biophys. Res. Commun. 244, 253-257. doi: 10.1006/bbrc.1998.8159

Park, J., Yang, S., Kim, Y., Kim, J.-C., Dang, Q., Kim, J., et al. (2012). Antiviral peptide from Pseudomonas chlororaphis O6 against tobacco mosaic virus (TMV). J. Korean Soc. Appl. Biol. Chem. 55, 89-94. doi: 10.1007/s13765-0120015-2

Park, J. M., Jung, J. E., and Lee, B. J. (1994). Antimicrobial peptides from the skin of a Korean frog, Rana rugosa. Biochem. Biophys. Res. Commun. 205, 948-954. doi: 10.1006/bbrc.1994.2757

Pepe, G., Tenore, G. C., Mastrocinque, R., Stusio, P., and Campiglia, P. (2013). Potential anticarcinogenic peptides from bovine milk. J. Amino Acids 2013:939804. doi: 10.1155/2013/939804
Peter, B. M., Shirtliff, M. E., and Jabra-Rizk, M. A. (2010). Antimicrobial peptides: primeval molecules or future drugs? Plos Pathog 6:e1001067. doi: 10.1371/ journal.ppat.1001067

Pichereau, C., and Allary, C. (2005). Therapeutic peptides under the spotlight. Eur. Biopharm. Rev. 5, 88-91.

Power, O., Jakeman, P., and Fitzgerald, R. J. (2013). Antioxidative peptides: enzymatic production, in vitro and in vivo antioxidant activity and potential applications of milk-derived antioxidative peptides. Amino Acids 44, 797-820. doi: 10.1007/s00726-012-1393-9

Puddu, P., Borghi, P., Gessani, S., Valenti, P., Belardelli, F., and Seganti, L. (1998). Antiviral effect of bovine lactoferrin saturated with metal ions on early steps of human immunodeficiency virus type 1 infection. Int. J. Biochem. Cell Biol. 30, 1055-1062. doi: 10.1016/S1357-2725(98)00066-1

Rashid, M. A., Gustafson, K. R., Cartner, L. K., Shigematsu, N., Pannell, L. K., and Boyd, M. R. (2001). Microspinosamide, a new HIV-inhibitory cyclic depsipeptide from the marine sponge Sidonops microspinosa. J. Nat. Prod. 64, 117-121. doi: 10.1021/np0002379

Reichert, J., Pechon, P., Tartar, A., and Dunn, M. K. (2010). Report summary: development trends for peptide therapeutics. Pept. Ther. Found. 1-11.

Renan, M. J. (1993). How many mutations are required for tumorigenesis. Implications from human cancer data. Mol. Carcinog. 7, 139-146. doi: 10.1002/mc. 2940070303

Riedl, S., Zweytick, D., and Lohner, K. (2011). Membrane-active host defense peptides-challenges and perspectives for the development of novel anticancer drugs. Chem. Phys. Lipids 164, 766-781. doi: 10.1016/j.chemphyslip.2011. 09.004

Rinehart, K. L. Jr., Gloer, J. B., Hughes, R. G. Jr., Renis, H. E., McGovren, J. P., Swynenberg, E. B., et al. (1981). Didemnins: antiviral and antitumor depsipeptides from a caribbean tunicate. Science 212, 933-935. doi: 10.1126/science.7233187

Rinehart, K. L. Jr., Gloer, J. B., Wilson, G. R., Hughes, R. G. Jr., Li, L. H., Renis, H. E., et al. (1983). Antiviral and antitumor compounds from tunicates. Fed. Proc. 42, 87-90.

Risso, A., Braidot, E., Sordano, M. C., Vianello, A., Macri, F., Skerlavaj, B., et al. (2002). BMAP-28, an antibiotic peptide of innate immunity, induces cell death through opening of the mitochondrial permeability transition pore. Mol. Cell. Biol. 22, 1926-1935. doi: 10.1128/MCB.22.6.1926-1935.2002

Risso, A., Zanetti, M., and Gennaro, R. (1998). Cytotoxicity and apoptosis mediated by two peptides of innate immunity. Cell. Immunol. 189, 107-115. doi: 10.1006/cimm.1998.1358

Robinson, W. E. Jr., McDougall, B., Tran, D., and Selsted, M. E. (1998). Anti-HIV1 activity of indolicidin, an antimicrobial peptide from neutrophils. J. Leukoc. Biol. 63, 94-100.

Rotem, S., and Mor, A. (2009). Antimicrobial peptide mimics for improved therapeutic properties. Biochim. Biophys. Acta 1788, 1582-1592. doi: 10.1016/j.bbamem.2008.10.020

Rozek, T., Wegener, K. L., Bowie, J. H., Olver, I. N., Carver, J. A., Wallace, J. C., et al. (2000). The antibiotic and anticancer active aurein peptides from the Australian Bell Frogs Litoria aurea and Litoria raniformis the solution structure of aurein 1.2. Eur. J. Biochem. 267, 5330-5341. doi: 10.1046/j.1432-1327.2000. 01536.x

Sandgren, S., Wittrup, A., Cheng, F., Jonsson, M., Eklund, E., Busch, S., et al. (2004). The human antimicrobial peptide LL-37 transfers extracellular DNA plasmid to the nuclear compartment of mammalian cells via lipid rafts and proteoglycan-dependent endocytosis. J. Biol. Chem. 279, 17951-17956. doi: 10.1074/jbc.M311440200

Schweizer, F. (2009). Cationic amphiphilic peptides with cancer-selective toxicity. Eur. J. Pharmacol. 625, 190-194. doi: 10.1016/j.ejphar.2009.08.043

Sen, Z., Zhan, X. K., Jing, J., Yi, Z., and Wanqi, Z. (2013). Chemosensitizing activities of cyclotides from Clitoria ternatea in paclitaxel-resistant lung cancer cells. Oncol. Lett. 5, 641-644. doi: 10.3892/ol.2012.1042

Sharma, S. V. (1992). Melittin resistance: a counterselection for ras transformation. Oncogene 7, 193-201.

Sharma, S. V. (1993). Melittin-induced hyperactivation of phospholipase A2 activity and calcium influx in ras-transformed cells. Oncogene 8, 939-947.

Shimizu, K., Matsuzawa, H., Okada, K., Tazume, S., Dosako, S., Kawasaki, Y., et al. (1996). Lactoferrin-mediated protection of the host from murine cytomegalovirus infection by a T-cell-dependent augmentation of natural killer cell activity. Arch. Virol. 141, 1875-1889. doi: 10.1007/BF01718201 
Silva, O. N., Porto, W. F., Migliolo, L., Mandal, S. M., Gomes, D. G., Holanda, H. H., et al. (2012). Cn-AMP1: a new promiscuous peptide with potential for microbial infections treatment. Biopolymers 98, 322-331. doi: 10.1002/bip.22071

Silvestro, L., Gupta, K., Weiser, J. N., and Axelsen, P. H. (1999). The concentrationdependent membrane activity of cecropin A. Biochemistry 38, 3850. doi: 10.1021/bi995071t

Simons, K., and Ikonen, E. (2000). How cells handle cholesterol. Science 290, 1721-1726. doi: 10.1126/science.290.5497.1721

Singh, R., Sharma, M., Joshi, P., and Rawat, D. S. (2008). Clinical status of anticancer agents derived from marine sources. Anticancer Agents Med. Chem. 8, 603-617. doi: 10.2174/187152008785133074

Sinha, S., Cheshenko, N., Lehrer, R. I., and Herold, B. C. (2003). NP-1, a rabbit alpha-defensin, prevents the entry and intercellular spread of herpes simplex virus type 2. Antimicrob. Agents Chemother. 47, 494-500. doi: 10.1128/AAC.47.2.494-500.2003

Smith, L. L., Brown, K., Carthew, P., Lim, C. K., Martin, E. A., Styles, J., et al. (2000). Chemoprevention of breast cancer by tamoxifen: risks and opportunities. Crit. Rev. Toxicol. 30, 571-594. doi: 10.1080/10408440008951120

Sok, M., Sentjurc, M., and Schara, M. (1999). Membrane fluidity characteristics of human lung cancer. Cancer Lett. 139, 215-220. doi: 10.1016/S03043835(99)00044-0

Srisailam, S., Kumar, T. K., Arunkumar, A. I., Leung, K. W., Yu, C., and Chen, H. M. (2001). Crumpled structure of the custom hydrophobic lytic peptide cecropin B3. Eur. J. Biochem. 268, 4278-4284. doi: 10.1046/j.1432-1327.2001.02345.x

Steiner, H., Hultmark, D., Engstrom, A., Bennich, H., and Boman, H. G. (1981). Sequence and specificity of two antibacterial proteins involved in insect immunity. Nature 292, 246-248. doi: 10.1038/292246a0

Steinstraesser, L., Tippler, B., Mertens, J., Lamme, E., Homann, H. H., Lehnhardt, M., et al. (2005). Inhibition of early steps in the lentiviral replication cycle by cathelicidin host defense peptides. Retrovirology 2, 2. doi: 10.1186/17424690-2-2

Sui, S. F., Wu, H., Guo, Y., and Chen, K. S. (1994). Conformational changes of melittin upon insertion into phospholipid monolayer and vesicle. J. Biochem. $116,482-487$.

Suttmann, H., Retz, M., Paulsen, F., Harder, J., Zwergel, U., Kamradt, J., et al. (2008). Antimicrobial peptides of the Cecropin-family show potent antitumor activity against bladder cancer cells. BMC Urol. 8:5. doi: 10.1186/1471-2490-8-5

Szakacs, G., Paterson, J. K., Ludwig, J. A., Booth-Genthe, C., and Gottesman, M. M. (2006). Targeting multidrug resistance in cancer. Nat. Rev. Drug Discov. 5, 219-234. doi: 10.1038/nrd1984

Takeshima, K., Chikushi, A., Lee, K. K., Yonehara, S., and Matsuzaki, K. (2003). Translocation of analogues of the antimicrobial peptides magainin and buforin across human cell membranes. J. Biol. Chem. 278, 1310-1315. doi: 10.1074/jbc.M208762200

Tamamura, H., Otaka, A., Murakami, T., Ishihara, T., Ibuka, T., Waki, M., et al. (1996). Interaction of an anti-HIV peptide, T22, with gp120 and CD4. Biochem. Biophys. Res. Commun. 219, 555-559. doi: 10.1006/bbrc. 1996.0272

Tamamura, H., Xu, Y., Hattori, T., Zhang, X., Arakaki, R., Kanbara, K., et al. (1998). A low-molecular-weight inhibitor against the chemokine receptor CXCR4: a strong anti-HIV peptide T140. Biochem. Biophys. Res. Commun. 253, 877-882. doi: 10.1006/bbrc.1998.9871

Tavares, L. S., Rettore, J. V., Freitas, R. M., Porto, W. F., Duque, A. P., Singulani, J. D., et al. (2012). Antimicrobial activity of recombinant PgAMP1, a glycine-rich peptide from guava seeds. Peptides 37, 294-300. doi: 10.1016/j.peptides.2012.07.017

Taylor, S., Massiah, A., Lomonossoff, G., Roberts, L. M., Lord, J. M., and Hartley, M. (1994). Correlation between the activities of five ribosome-inactivating proteins in depurination of tobacco ribosomes and inhibition of tobacco mosaic virus infection. Plant J. 5, 827-835. doi: 10.1046/j.1365-313X.1994. 5060827.x

Teixeira, L. D., Silva, O. N., Migliolo, L., Fensterseifer, I. C., and Franco, O. L. (2013). In vivo antimicrobial evaluation of an alanine-rich peptide derived from Pleuronectes americanus. Peptides 42, 144-148. doi: 10.1016/j.peptides.2013.02.001

Terras, F. R., Schoofs, H. M., De Bolle, M. F., Van Leuven, F., Rees, S. B., Vanderleyden, J., et al. (1992). Analysis of two novel classes of plant antifungal proteins from radish (Raphanus sativus L.) seeds. J. Biol. Chem. 267, 15301-15309.
Thakur, N., Qureshi, A., and Kumar, M. (2012). AVPpred: collection and prediction of highly effective antiviral peptides. Nucleic Acids Res. 40, W199-W204. doi: $10.1093 / \mathrm{nar} / \mathrm{gks} 450$

Thundimadathil, J. (2012). Cancer treatment using peptides: current therapies and future prospects. J. Amino Acids 2012, 1-13. doi: 10.1155/2012/967347

Tosteson, M. T., Holmes, S. J., Razin, M., and Tosteson, D. C. (1985). Melittin lysis of red cells. J. Membr. Biol. 87, 35-44. doi: 10.1007/BF01870697

Tripathi, G. R., Park, J., Park, Y., Hwang, I., Hahm, K. S., and Cheong, H. (2006). Potide-G derived from potato (Solanum tuberosum L.) is active against potato virus YO (PVYO) infection. J. Agric. Food Chem. 54, 8437-8443. doi: 10.1021/jf061794p

Valenti, P., and Antonini, G. (2005). Lactoferrin: an important host defence against microbial and viral attack. Cell. Mol. Life Sci. 62, 2576-2587. doi: 10.1007/s00018-005-5372-0

Van Der Strate, B. W., Beljaars, L., Molema, G., Harmsen, M. C., and Meijer, D. K. (2001). Antiviral activities of lactoferrin. Antivir. Res. 52, 225-239. doi: 10.1016/S0166-3542(01)00195-4

Vancompernolle, S. E., Taylor, R. J., Oswald-Richter, K., Jiang, J., Youree, B. E., Bowie, J. H., et al. (2005). Antimicrobial peptides from amphibian skin potently inhibit human immunodeficiency virus infection and transfer of virus from dendritic cells to T cells. J. Virol. 79, 11598-11606. doi: 10.1128/JVI.79.18.11598-11606.2005

Vasko, R. C., Rodriguez, R. A., Cunningham, C. N., Ardi, V. C., Agard, D. A., and McAlpine, S. R. (2010). Mechanistic studies of sansalvamide AAmide: an allosteric modulator of Hsp90. ACS Med. Chem. Lett. 1, 4-8. doi: $10.1021 / \mathrm{ml} 900003 \mathrm{t}$

Vervoort, H., Fenical, W., and Epifanio, R. A. (2000). Tamandarins A and B: new cytotoxic depsipeptides from a Brazilian ascidian of the family Didemnidae. J. Org. Chem. 65, 782-792. doi: 10.1021/jo991425a

Wachinger, M., Kleinschmidt, A., Winder, D., Von Pechmann, N., Ludvigsen, A., Neumann, M., et al. (1998). Antimicrobial peptides melittin and cecropin inhibit replication of human immunodeficiency virus 1 by suppressing viral gene expression. J. Gen. Virol. 79(Pt 4), 731-740.

Wagner, E. K., Hewlett, M. J., Bloom, D. C., and Camerini, D. (1999). Basic Virology. Boston, MA: Wiley-Blackwell.

Wang, C., Chen, T., Zhang, N., Yang, M., Li, B., Lu, X., et al. (2009a) Melittin, a major component of bee venom, sensitizes human hepatocellular carcinoma cells to tumor necrosis factor-related apoptosis-inducing ligand (TRAIL)-induced apoptosis by activating CaMKII-TAK1-JNK/p38 and inhibiting IkappaBalpha kinase-NFkappaB. J. Biol. Chem. 284, 3804-3813. doi: 10.1074/jbc.M807191200

Wang, A., Wang, S., Shen, M., Chen, F., Zou, Z., Ran, X., et al. (2009b). High level expression and purification of bioactive human alpha-defensin 5 mature peptide in Pichia pastoris. Appl. Microbiol. Biotechnol. 84, 877-884. doi: 10.1007/s00253-009-2020-X

Wang, Y.-D., Kung, C.-W., and Chen, J.-Y. (2010a). Antiviral activity by fish antimicrobial peptides of epinecidin-1 and hepcidin 1-5 against nervous necrosis virus in medaka. Peptides 31, 1026-1033. doi: 10.1016/j.peptides.2010.02.025

Wang, A., Su, Y., Wang, S., Shen, M., Chen, F., Chen, M., et al. (2010b). High efficiency preparation of bioactive human alpha-defensin 6 in Escherichia col Origami(DE3)pLysS by soluble fusion expression. Appl. Microbiol. Biotechnol. 87, 1935-1942. doi: 10.1007/s00253-010-2688-y

Wang, Q., Zhu, F., Xin, Y., Liu, J., Luo, L., and Yin, Z. (2011). Expression and purification of antimicrobial peptide buforin IIb in Escherichia coli. Biotechnol. Lett. 33, 2121-2126. doi: 10.1007/s10529-011-0687-4

Wang, C., Liu, M., Cheng, L., Wei, J., Wu, N., Zheng, L., et al. (2012). A novel polypeptide from Meretrix meretrix Linnaeus inhibits the growth of human lung adenocarcinoma. Exp. Biol. Med. 237, 442-450. doi: 10.1258/ebm.2012.011337

Wang, X., and Zhang, X. (2013). Separation, antitumor activities, and encapsulation of polypeptide from Chlorella pyrenoidosa. Biotechnol. Prog. 29, 681-687. doi: 10.1002/btpr.1725

Watters, D. J., Beamish, H. J., Marshall, K. A., Gardiner, R. A., Seymour, G. J., and Lavin, M. F. (1994). Accumulation of HL-60 leukemia cells in G2/M and inhibition of cytokinesis caused by two marine compounds, bistratene A and cycloxazoline. Cancer Chemother. Pharmacol. 33, 399-409. doi: 10.1007/ BF00686269

Wele, A., Zhang, Y., Ndoye, I., Brouard, J. P., Pousset, J. L., and Bodo, B. (2004). A cytotoxic cyclic heptapeptide from the seeds of Annona cherimola. J. Nat. Prod. 67, 1577-1579. doi: 10.1021/np040068i 
Wesson, K. J., and Hamann, M. T. (1996). Keenamide, A, a bioactive cyclic peptide from the marine mollusk Pleurobranchus forskalii. J. Nat. Prod. 59, 629-631. doi: $10.1021 / \mathrm{np} 960153 \mathrm{t}$

Westerhoff, H. V., Hendler, R. W., Zasloff, M., and Juretić, D. (1989). Interactions between a new class of eukaryotic antimicrobial agents and isolated rat liver mitochondria. Biochim. Biophys. Acta 3, 3. doi: 10.1016/S0005-2728(89)80344-5

Williams, P. G., Luesch, H., Yoshida, W. Y., Moore, R. E., and Paul, V. J. (2003). Continuing studies on the cyanobacterium Lyngbya sp.: isolation and structure determination of 15-norlyngbyapeptin A and lyngbyabellin D. J. Nat. Prod. 66, 595-598. doi: 10.1021/np030011g

Won, H. S., Seo, M. D., Jung, S. J., Lee, S. J., Kang, S. J., Son, W. S., et al. (2006). Structural determinants for the membrane interaction of novel bioactive undecapeptides derived from gaegurin 5. J. Med. Chem. 49, 4886-4895. doi: 10.1021/jm050996u

Xu, J. X., and Jin, S. (1999). Studies on synthesis, structure and antitumor activities of analogues of Papaver somniferum pollen tridecapepide. Chem. J. Chinese Univ. 20, 722-726.

Xu, Z., Peng, L., Zhong, Z., Fang, X., and Cen, P. (2006). High-level expression of a soluble functional antimicrobial peptide, human beta-defensin 2, in Escherichia coli. Biotechnol. Prog. 22, 382-386. doi: 10.1021/bp0502680

Xu, X., Jin, F., Yu, X., Ji, S., Wang, J., Cheng, H., et al. (2007a). Expression and purification of a recombinant antibacterial peptide, cecropin, from Escherichia coli. Protein Expr. Purif. 53, 293-301. doi: 10.1016/j.pep. 2006.12.020

Xu, X., Jin, F., Yu, X., Ren, S., Hu, J., and Zhang, W. (2007b). High-level expression of the recombinant hybrid peptide cecropinA(1-8)-magainin2 with an ubiquitin fusion partner in Escherichia coli. Protein Expr. Purif. 55, 175-182. doi: 10.1016/j.pep.2007.04.018

Xu, N., Wang, Y. S., Pan, W. B., Xiao, B., Wen, Y. J., Chen, X. C., et al. (2008). Human alpha-defensin-1 inhibits growth of human lung adenocarcinoma xenograft in nude mice. Mol. Cancer Ther. 7, 1588-1597. doi: 10.1158/15357163.MCT-08-0010

Yan, R., Zhao, Z., He, Y., Wu, L., Cai, D., Hong, W., et al. (2011). A new natural alpha-helical peptide from the venom of the scorpion Heterometrus petersii kills HCV. Peptides 32, 11-19. doi: 10.1016/j.peptides.2010.10.008

Yang, Q.-Z., Wang, C., Lang, L., Zhou, Y., Wang, H., and Shang, D.-J. (2013). Design of potent, non-toxic anticancer peptides based on the structure of the antimicrobial peptide, temporin-1CEa. Arch. Pharm. Res. doi: 10.1007/s12272-0130112-8. [Epub ahead of print].

Yasin, B., Pang, M., Turner, J. S., Cho, Y., Dinh, N. N., Waring, A. J., et al. (2000). Evaluation of the inactivation of infectious Herpes simplex virus by host-defense peptides. Eur. J. Clin. Microbiol. Infect. Dis. 19, 187-194. doi: 10.1007/s100960050457

Yasin, B., Wang, W., Pang, M., Cheshenko, N., Hong, T., Waring, A. J., et al. (2004). Theta defensins protect cells from infection by herpes simplex virus by inhibiting viral adhesion and entry. J. Virol. 78, 5147-5156. doi: 10.1128/JVI.78.10.5147-5156.2004

Yeaman, M. R., and Yount, N. Y. (2003). Mechanisms of antimicrobial peptide action and resistance. Pharmacol. Rev. 55, 27-55. doi: 10.1124/pr.55.1.2

Yi, M., Kaneko, S., Yu, D. Y., and Murakami, S. (1997). Hepatitis C virus envelope proteins bind lactoferrin. J. Virol. 71, 5997-6002.

Yoo, Y. C., Watanabe, R., Koike, Y., Mitobe, M., Shimazaki, K., Watanabe, S., et al. (1997). Apoptosis in human leukemic cells induced by lactoferricin, a bovine milk protein-derived peptide: involvement of reactive oxygen species. Biochem. Biophys. Res. Commun. 237, 624-628. doi: 10.1006/bbrc.1997.7199
Yu, Z., Lang, G., Kajahn, I., Schmaljohann, R., and Imhoff, J. F. (2008). Scopularides A and B, cyclodepsipeptides from a marine sponge-derived fungus, Scopulariopsis brevicaulis. J. Nat. Prod. 71, 1052-1054. doi: 10.1021/np070580e

Zakharchenko, N. S., Kalyaeva, M. A., and Buryanov, Y. I. (2013). Expression of cecropin P1 gene increases resistance of Camelina sativa(L.) plants to microbial phytopathogenes. Russ. J. Genet. 49, 523-529. doi: 10.1134/S102279541305013X

Zampella, A., Sepe, V., Bellotta, F., Luciano, P., D'auria, M. V., Cresteil, T., et al. (2009). Homophymines B-E and A1-E1, a family of bioactive cyclodepsipeptides from the sponge Homophymia sp. Org. Biomol. Chem. 7, 4037-4044. doi: $10.1039 / \mathrm{b} 910015 \mathrm{f}$

Zasloff, M. (1987). Magainins, a class of antimicrobial peptides from Xenopus skin: isolation, characterization of two active forms, and partial cDNA sequence of a precursor. Proc. Natl. Acad. Sci. U.S.A. 84, 5449-5453. doi: 10.1073/pnas.84.15.5449

Zhang, J., Mulvenon, A., Makarov, E., Wagoner, J., Knibbe, J., Kim, J. O., et al. (2013a). Antiviral peptide nanocomplexes as a potential therapeutic modality for HIV/HCV co-infection. Biomaterials 34, 3846-3857. doi: 10.1016/j.biomaterials.2013.01.026

Zhang, J., Tian, H., Li, C., Cheng, L., Zhang, S., Zhang, X., et al. (2013b). Antitumor effects obtained by autologous Lewis lung cancer cell vaccine engineered to secrete mouse Interleukin 27 by means of cationic liposome. Mol. Immunol. 55, 264- 274. doi: 10.1016/j.molimm.2013.02.006

Zhang, L. H., and Longley, R. E. (1999). Induction of apoptosis in mouse thymocytes by microcolin A and its synthetic analog. Life Sci. 64, 1013-1028. doi: 10.1016/S0024-3205(99)00028-4

Zhang, X. X., Eden, H. S., and Chen, X. (2012). Peptides in cancer nanomedicine: drug carriers, targeting ligands and protease substrates. J. Control. Release 159, 2-13. doi: 10.1016/j.jconrel.2011.10.023

Zhao, Y., Cai, X., Ye, T., Huo, J., Liu, C., Zhang, S., et al. (2011). Analgesic-antitumor peptide inhibits proliferation and migration of SHG-44 human malignant glioma cells. J. Cell. Biochem. 112, 2424-2434. doi: 10.1002/jcb.23166

Zheng, L. H., Wang, Y. J., Sheng, J., Wang, F., Zheng, Y., Lin, X. K., et al. (2011). Antitumor peptides from marine organisms. Mar. Drugs 9, 1840-1859. doi: 10.3390/md9101840

Zhong, Z., Xu, Z., Peng, L., Huang, L., Fang, X., and Cen, P. (2006). Tandem repeat mhBD2 gene enhance the soluble fusion expression of hBD2 in Escherichia coli. Appl. Microbiol. Biotechnol. 71, 661-667. doi: 10.1007/s00253-005-0212-6

Conflict of Interest Statement: The authors declare that the research was conducted in the absence of any commercial or financial relationships that could be construed as a potential conflict of interest.

Received: 12 August 2013; paper pending published: 08 September 2013; accepted: 11 October 2013; published online: 31 October 2013.

Citation: Mulder KCL, Lima LA, Miranda VJ, Dias SC and Franco OL (2013) Current scenario of peptide-based drugs: the key roles of cationic antitumor and antiviral peptides. Front. Microbiol. 4:321. doi: 10.3389/fmicb.2013.00321

This article was submitted to Antimicrobials, Resistance and Chemotherapy, a section of the journal Frontiers in Microbiology.

Copyright (c) 2013 Mulder, Lima, Miranda, Dias and Franco. This is an openaccess article distributed under the terms of the Creative Commons Attribution License (CC BY). The use, distribution or reproduction in other forums is permitted, provided the original author(s) or licensor are credited and that the original publication in this journal is cited, in accordance with accepted academic practice. No use, distribution or reproduction is permitted which does not comply with these terms. 